\title{
Nitrogen uptake by phytoplankton in the Atlantic sector of the Southern Ocean during late austral summer
}

\author{
W. R. Joubert ${ }^{1,2}$, S. J. Thomalla ${ }^{1,2}$, H. N. Waldron ${ }^{2}$, M. I. Lucas ${ }^{3}$, M. Boye ${ }^{4}$, F. A. C. Le Moigne ${ }^{4}$, F. Planchon ${ }^{4}$, and \\ S. Speich ${ }^{5}$ \\ ${ }^{1}$ Council for Scientific and Industrial Research, P.O. Box 320, Stellenbosch, 7599, South Africa \\ ${ }^{2}$ Department of Oceanography, University of Cape Town, Private Bag X3, 7701, South Africa \\ ${ }^{3}$ Department of Zoology, University of Cape Town, Private Bag X3, 7701, South Africa \\ ${ }^{4}$ Laboratoire des Sciences de l'Environment Marin, UMR6539 UBO/CNRS/IRD, Institut Universitaire Européen de la Mer, \\ Technopôle Brest Iroise, Place Nicolas Copernic, 29 280, Plouzané, France \\ ${ }^{5}$ Laboratoire de Physique des Oceans (LPO), UMR6523 CNRS/IFREMER/IRD/UBO-IUEM, Centre Ifremer, BP70, 29820 \\ Plouzané France
}

Received: 6 April 2011 - Published in Biogeosciences Discuss.: 23 May 2011

Revised: 30 September 2011 - Accepted: 6 October 2011 - Published: 21 October 2011

\begin{abstract}
As part of the Bonus-GoodHope (BGH) campaign, ${ }^{15} \mathrm{~N}$-labelled nitrate, ammonium and urea uptake measurements were made along the $\mathrm{BGH}$ transect from Cape Town to $\sim 60^{\circ} \mathrm{S}$ in late austral summer, 2008. Our results are categorised according to distinct hydrographic regions defined by oceanic fronts and open ocean zones. High regenerated nitrate uptake rate in the oligotrophic Subtropical Zone (STZ) resulted in low $f$-ratios $(f=0.2)$ with nitrogen uptake being dominated by $\rho$ urea, which contributed up to $70 \%$ of total nitrogen uptake. Size fractionated chlorophyll data showed that the greatest contribution $(>50 \%)$ of picophytoplankton $(<2 \mu \mathrm{m})$ were found in the STZ, consistent with a community based on regenerated production. The Subantarctic Zone (SAZ) showed the greatest total integrated nitrogen uptake (10.3 mmol m $\left.\mathrm{m}^{-2} \mathrm{~d}^{-1}\right)$, mainly due to enhanced nutrient supply within an anticyclonic eddy observed in this region. A decrease in the contribution of smaller size classes to the phytoplankton community was observed with increasing latitude, concurrent with a decrease in the contribution of regenerated production. Higher $f$-ratios observed in the SAZ $(f=0.49)$, Polar Frontal Zone $(f=0.41)$ and Antarctic Zone $(f=0.45)$ relative to the STZ $(f=0.24)$, indicate a higher contribution of $\mathrm{NO}_{3}^{-}$-uptake relative to total nitrogen and potentially higher export production. High ambient regenerated nutrient concentrations are indicative of active regeneration processes throughout the transect and ascribed to late summer season sampling. Higher depth integrated
\end{abstract}

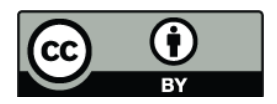

Correspondence to: W. R. Joubert (wjoubert@csir.co.za) uptake rates also correspond with higher surface iron concentrations. No clear correlation was observed between carbon export estimates derived from new production and ${ }^{234} \mathrm{Th}$ flux. In addition, export derived from ${ }^{15} \mathrm{~N}$ estimates were $2-$ 20 times greater than those based on ${ }^{234} \mathrm{Th}$ flux. Variability in the magnitude of export is likely due to intrinsically different methods, compounded by differences in integration time scales for the two proxies of carbon export.

\section{Introduction}

The Southern Ocean is considered one of the most important ocean sinks of atmospheric $\mathrm{CO}_{2}$ (Caldeira and Duffy, 2000; Sigman and Boyle, 2000), making it important in understanding the global carbon cycle. Primary productivity in the Southern Ocean plays a key role in the biological uptake of atmospheric $\mathrm{CO}_{2}$ (Metzl et al., 1999; Takahashi et al., 2002). Phytoplankton biomass typically shows low chlorophyll a $(\mathrm{chl}-a)\left(<0.5 \mathrm{mg} \mathrm{m}^{-3}\right)$ in open ocean waters of the Southern Ocean (Tréguer and Jacques, 1992; Banse, 1996; Moore and Abbott, 2000), while localised elevated chl- $a$ (>1 $\mathrm{mg} \mathrm{m}^{-3}$; Moore and Abbott, 2000) are often associated with mesoscale upwelling at hydrographic fronts (Laubscher et al., 1993; Comiso et al., 1993; Moore and Abbott, 2002; Sokolov and Rintoul, 2007), the marginal ice zone (MIZ) (Smith and Nelson, 1986; Sedwick and DiTullio, 1997) and regions of shallow bathymetry around Subantarctic islands (Blain et al., 2001; Pollard et al., 2002; Korb and Whitehouse, 2004; Seeyave et al., 2007; Whitehouse et al., 2008). Under-utilization of available macronutrients by

Published by Copernicus Publications on behalf of the European Geosciences Union. 
phytoplankton production results in the prevalent high nutrient low chl- $a$ (HNLC) condition (Chisholm and Morel, 1991) of the Southern Ocean. Despite a high inventory of available macronutrients, low chl- $a$ concentrations are maintained by bottom-up controls of phytoplankton production through light, iron, and silicate limitation (Martin et al., 1990; Bathmann et al., 1997; Boyd et al., 2001, 2002, 2007; Moore and Abbott, 2002; Arrigo et al., 2008), as well as by top-down grazing control (Banse, 1996; Cullen, 1991; Price et al., 1994; Smetacek et al., 2004; Behrenfeld, 2010). These factors regulating primary production all modify carbon export and thus play a key role in determining the strength of the Southern Ocean biological carbon pump.

Measurements of phytoplankton production throughout the euphotic layer using ${ }^{15} \mathrm{~N}$ stable isotopes (Dugdale and Goering, 1967) have often been used to infer carbon export into the ocean interior based on the $f$-ratio (Eppley and Peterson, 1979; Savoye et al., 2004). The $f$-ratio differentiates between the uptake of $\mathrm{NO}_{3}^{-}$by phytoplankton which is "new" to the euphotic layer, introduced primarily by seasonal overturning or upwelling and "regenerated" nutrient uptake $\left(\mathrm{NH}_{4}^{+}\right.$, urea and dissolved organic nitrogen (DON)) which is recycled within the euphotic layer (Eppley and Peterson, 1979). As nitrogen flux into surface waters must ultimately be balanced by equivalent losses, the $f$-ratio is a measure of that fraction of primary production, which is potentially available for export to the deep ocean or to higher trophic levels; which is surplus to phytoplanktonic community maintenance requirements (Goeyens et al., 1998). $\mathrm{NO}_{3}^{-}$uptake can thus provide an indirect estimate of downward carbon flux when Redfield ratio stoichiometry is inferred or measured (Eppley and Peterson, 1979). This approach to measuring carbon export relies on a number of underlying assumptions which include steady state conditions (uptake flux of $\mathrm{NO}_{3}^{-}$ approximately balanced by particulate nitrogen flux out of the surface), no storage of nitrogen in surface waters (Eppley and Peterson, 1979), and minimal euphotic layer nitrification (Bianchi et al., 1996; Yool et al., 2007). In addition, the use of stoichiometric ratios to convert nitrogen uptake $(\rho \mathrm{N}$ to carbon equivalents may be compromised by non-Redfield behaviour in the cellular response to available light, iron and nutrients (Brzezenski et al., 2003; Arrigo, 2005; Moore et al., 2007). Although nitrification in surface waters is particularly important in oligotrophic ocean regions, this process does not appear to be significant in nitrate replete environments (Yool et al., 2007; Lucas et al., 2007; Clark et al., 2008). Despite its limitations, the $f$-ratio therefore remains a useful proxy for estimating potentially "exportable production" (Sambrotto and Mace, 2000) in nutrient rich polar oceans.

Carbon export estimates are also possible using ${ }^{234} \mathrm{Th} /{ }^{238} \mathrm{U}$ disequilibrium (e.g. Buesseler, 1992). Lower activities of particle-reactive ${ }^{234} \mathrm{Th}$ relative to its conservative parent ${ }^{238} \mathrm{U}$ in surface waters are associated with sinking particles. Particulate Organic Carbon (POC) export is calculated as the product of the ratio of $\mathrm{POC} /{ }^{234} \mathrm{Th}$ on set-

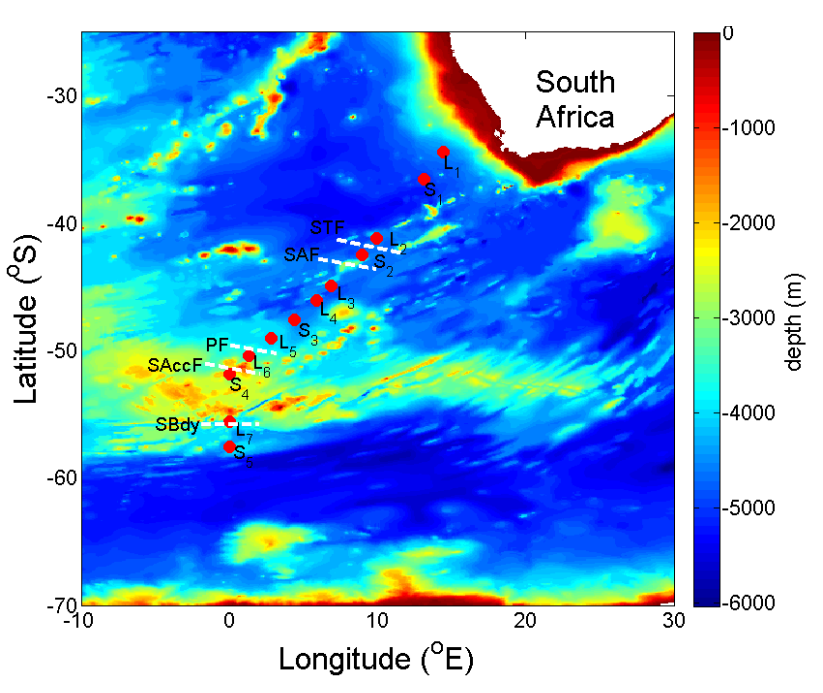

Fig. 1. Cruise track during the Bonus Goodhope 2008 campaign in the Atlantic Southern Ocean. Red dots indicate the sampling positions for ${ }^{15} \mathrm{~N}$ uptake experiments. The hydrographic fronts, Subtropical Front (STF), Sub-Antarctic Front (SAF), Polar Front (PF), South Antarctic Circumpolar Current Front (SAccF) and Southern Boundary (Sbdy) are indicated by dotted white lines.

tling particles and the ${ }^{234} \mathrm{Th}$ disequilibrium flux (Coale and Bruland, 1985). Uncertainties associated with this method relate to varying measurement techniques and choice of models (steady-state vs non steady state). In addition, arguably the largest uncertainty in the application of the thorium approach lies in reliably characterising the ratio of POC: ${ }^{234} \mathrm{Th}$ on settling particles, which varies with time, depth, particle type, size and sinking velocity (for review see Buesseler et el., 2006). Despite all the uncertainties associated with the various proxies of carbon export, it is nonetheless useful to compare a variety of export estimates as they access different time and space scales.

This paper reports measurements of new and regenerated uptake rates and $f$-ratios (as a proxy for export) in surface waters of the Atlantic sector of the Southern Ocean in late austral summer 2008 as part of the BGH programme. The cruise crossed a number of mesoscale features and major hydrographic fronts; namely the Subtropical Front (STF), the Sub-Antarctic Front (SAF), the Polar Front (PF), the Southern Antarctic Circumpolar Current Front (SAccF) and the Southern Boundary (Sbdy) (Fig. 1). Results from this study characterise $\rho \mathrm{N}$ dynamics and $f$-ratios across different hydrographic regions and investigates their relation to MLD, light, macro-nutrient and dissolved surface iron concentrations. We compare our data with ${ }^{15} \mathrm{~N}$ estimates of production in other areas of the Southern Ocean, as well as with ${ }^{234} \mathrm{Th}$ based estimates of carbon export measured during the BGH cruise. 


\section{Methods}

\subsection{Sampling and cruise track}

The sampling cruise on board the R/V Marion Dufresne was conducted from 8 February-18 March 2008. The cruise transect (Fig. 1) started on the shelf outside Cape Town (South Africa) at the $200 \mathrm{~m}$ isobath and followed the GoodHope A21 transect in a south-westerly direction to the $0^{\circ}$ meridian, then continued south to $58^{\circ} \mathrm{S}$. A total of 79 sampling stations were completed, 12 of which were targeted for $\rho \mathrm{N}$ incubations using ${ }^{15} \mathrm{~N}$ tracer techniques (Slawyk and Collos, 1977; Dugdale and Wilkerson, 1986).

\subsection{Hydrography}

Water mass characteristics of the section sampled were determined from temperature, salinity measured with a CTD (SEABIRD 911plus) mounted on a SEABIRD rosette. Onboard thermosalinograph (SEABIRD SBE21) data were collected in continuous mode at $5 \mathrm{~m}$ below sea level. Thermosalinograph data was validated with daily water sampling followed by on-board analysis. Mixed layer depths were determined using the temperature criteria $\left(\Delta T<0.2^{\circ} \mathrm{C}\right.$ in reference to the temperature at $10 \mathrm{~m}$ depth, de Boyer-Montégut et al., 2004).

\subsection{Nutrient analyses}

Ambient concentrations of $\mathrm{NH}_{4}^{-}$and urea- $\mathrm{N}$ were determined manually by the colorimetric method of Grasshoff et al. (1983), scaled to $5 \mathrm{ml}$ samples. Ambient $\mathrm{NO}_{3}^{-}$and $\mathrm{Si}(\mathrm{OH})_{4}-\mathrm{Si}$ concentrations were analyzed on a Bran and Lubbe AAIII autoanalyser, as described in Tréguer and Lecorre (1975).

\subsection{Chlorophyll- $a$}

Total chl- $a$ samples were collected in the upper $300 \mathrm{~m}$ at 6 depths from all CTD stations and 10 depths at all the $\rho \mathrm{N}$ experiment stations. The samples were filtered onto $25 \mathrm{~mm}$ Whatman GF/F filters, extracted in $6 \mathrm{ml}$ Acetone prior to fluorometric determination on a Turner Designs AU-10 fluorometer (Strickland and Parsons, 1972). Phaeopigments were determined by reading the fluorescence after acidification with 2-3 drops of $10 \%$ hydrochloric acid. Sizefractionated chl- $a$ determinations were collected opportunistically from surface water sampling. Size-fractionated chl$a$ concentrations were determined by screening samples through a $200 \mu \mathrm{m}$ mesh $(<200 \mu \mathrm{m}$ fraction), and a $20 \mu \mathrm{m}$ mesh ( $<20 \mu \mathrm{m}$ fraction), followed by filtration onto Whatman $\mathrm{GF} / \mathrm{F}$ filters. The $<2 \mu \mathrm{m}$ fraction was obtained by filtering a sample through a $2 \mu \mathrm{m}$ Nuclepore membrane filter and thereafter collecting the filtrate on a Whatman GF/F filter. Microphytoplankton $(20-200 \mu \mathrm{m})$ were determined by subtracting the $<20 \mu \mathrm{m}$ fraction from the $<200 \mu \mathrm{m}$ fraction; nanophytoplankton $(2-20 \mu \mathrm{m})$ by subtracting the $<2 \mu \mathrm{m}$ fraction from the $<20 \mu \mathrm{m}$ fraction, while picophytoplankton were represented by the $<2 \mu \mathrm{m}$ fraction. Chl- $a$ and phaeopigment concentrations of each fraction were determined as above.

\subsection{POC and PON}

Particulate organic carbon (POC) and nitrogen (PON) were determined by filtering 11 samples onto pre-ashed $25 \mathrm{~mm}$ Whatman GF/F filters that were frozen at $-20^{\circ} \mathrm{C}$ until analysis ashore. Samples were then oven-dried at $45^{\circ} \mathrm{C}$, acid fumed with sulphuric acid to drive off inorganic carbon and pelletted into tin cups $(8 \times 5 \mathrm{~mm})$ prior to analysis on a Thermo Scientific Flash EA1112 elemental CHN analyser.

\subsection{Nitrogen uptake measurements}

To determine depth integrated nitrogen uptake $\left(\int \rho \mathrm{N}\right.$, samples were collected at 5 underwater irradiance levels $(100 \%$, $50 \%, 25 \%, 10 \%$ and $1 \%$ ) measured using an underwater PAR (400-700 nm) sensor attached to the CTD rosette. Three bulk samples (21 each) from each light level were pre-screened through a $200 \mu \mathrm{m}$ plankton mesh to exclude zooplankton grazers and transferred into borosilicate glass Schott bottles. Aliquots of $200 \mu \mathrm{l}$ stock solutions of $\mathrm{K}^{15} \mathrm{NO}_{3}(1 \mu \mathrm{mol} / 100 \mu \mathrm{l}),{ }^{15} \mathrm{NH}_{4} \mathrm{Cl}(0.1 \mu \mathrm{mol} / 100 \mu \mathrm{l})$ and $\left.\mathrm{CO}\left({ }^{15} \mathrm{NH}_{2}\right)_{2}(0.1 \mu \mathrm{mol} / 100 \mu \mathrm{l})\right)$ were added, one to each of the three bottles from all light depths for $\rho \mathrm{N}$ incubations. The ${ }^{15} \mathrm{~N}$ enrichment was aimed at $\sim 10 \%$ for each nutrient, assuming an average ambient $\mathrm{NO}_{3}^{-}$concentration of $10 \mu \mathrm{moll}^{-1}$, and $1 \mu \mathrm{moll} \mathrm{l}^{-1}$ for $\mathrm{NH}_{4}^{+}$and urea. The inoculum was kept constant throughout the cruise and resulted in $\mathrm{NH}_{4}^{+}$enrichments that were greater than $10 \%$ of ambient concentrations (10-30\%). Incubation bottles were placed inside a Perspex tank covered with neutral density filters to recreate the appropriate light environment. Temperature was maintained at sea surface temperature (SST) by circulating surface water through the incubation tanks. Samples were incubated for $24 \mathrm{~h}$ and terminated by filtration onto ashed $47 \mathrm{~mm}$ Whatman $\mathrm{GF} / \mathrm{F}$ filters, which were then dried at $45^{\circ} \mathrm{C}$ before later isotopic analyses.

\subsection{Isotope analyses}

Particulate matter collected on the Whatman GF/F filters were pelletted and placed $8 \times 5 \mathrm{~mm}$ into tin capsules prior to isotopic analysis. Analyses were carried out on a Delta V Plus stable light isotope mass spectrometer interfaced to a Thermo Scientific Flash EA1112 Elemental Analyser. Natural abundance for nitrogen was 0.3663 atom $\%{ }^{15} \mathrm{~N}$, were used to calculate the isotopic enrichment of the nitrogen additions. Values were scaled upwards to reflect the proportion of the sub-sampled area relative to the total filtered area. Sulphanilamide and urea were used as calibration standards for carbon and nitrogen determinations. Specific uptake rates 
Table 1. List of abbreviations.

\begin{tabular}{ll}
\hline BGH & Bonus-GoodHope \\
HNLC & High nutrient low chlorophyll \\
STF & Subtropical Front $\left(\sim 42.2^{\circ} \mathrm{S}\right)$ \\
STZ & Subtropical Zone $($ equatorward of the STF $)$ \\
SAF & Sub Antarctic Front $\left(\sim 44.2^{\circ} \mathrm{S}\right)$ \\
SAZ & Sub-Antarctic Zone (equatorward of SAF) \\
PF & Polar Front $\left(\sim 50.1^{\circ} \mathrm{S}\right)$ \\
PFZ & Polar Front zone $($ equatorward of the PF) \\
SACCF & Southern Antarctic circumpolar Current Front $\left(\sim 51.5^{\circ} \mathrm{S}\right)$ \\
Sbdy & Southern Boundary of the Southern Ocean $\left(\sim 55.5^{\circ} \mathrm{S}\right)$ \\
AZ & Antarctic Zone (poleward of the Polar Front $)$ \\
SIZ & Seasonal Ice Zone \\
\hline
\end{tabular}

for nitrogen were calculated from the isotopic ratios of the particulate organic material at the end of the incubations as described by Dugdale and Wilkerson (1986), without correction for isotopic dilution in the case of $\mathrm{NH}_{4}^{+}$uptake. New production estimates were calculated from $\mathrm{NO}_{3}^{-}$uptake rates and in situ C:N ratios calculated from POC and PON samples.

\section{Results}

\subsection{Hydrography}

The BGH meridional cruise track crossed all the major hydrographic fronts and open ocean regions commonly recognised in the Southern Ocean (Orsi et al., 1995) (Fig. 1). The frontal positions during the cruise were determined using potential temperature criteria (Speich et al., 2011) (Fig. 2). The region north of the STF was defined as the Subtropical Zone (STZ) where SST exceeded $14{ }^{\circ} \mathrm{C}$ and salinity exceeded 35 psu (Fig. 2). The Sub-Antarctic zone (SAZ) lay between the STF $\left(42.2^{\circ} \mathrm{S}\right)$ and the $\operatorname{SAF}\left(44.2^{\circ} \mathrm{S}\right)$, where SST fell in the range $9-14{ }^{\circ} \mathrm{C}$, and surface salinity between 34-35 psu. In this zone, an intense anticyclonic eddy ("anticyclone M"; Arhan et al., 2011) of Indian Ocean origin was observed (at $42.9^{\circ} \mathrm{S}-44^{\circ} \mathrm{S}$ ) over the Agulhas Ridge (Fig. 2). The Polar Front Zone (PFZ) extended from the SAF to the PF (Pollard et al., 2002) at $50.1^{\circ} \mathrm{S}$, where SST decreased from $10-5^{\circ} \mathrm{C}$ and surface salinity was $<34 \mathrm{psu}$ (Fig. 2). The Antarctic Zone (AZ) was found south of the $\mathrm{PF}$ where temp was $<3^{\circ} \mathrm{C}$ and salinity was $\sim 34$ psu. The following results are presented according to the four zones defined above (STZ, SAZ, PFZ and AZ).

\subsection{Nutrients}

Nutrient concentrations shown in Fig. 3a, b are from the upper $200 \mathrm{~m}$ of the BGH cruise track (LeMoigne et al., 2011). In the STZ, surface nutrient concentrations (Fig. 3a, b) showed typical oligotrophic conditions, with surface

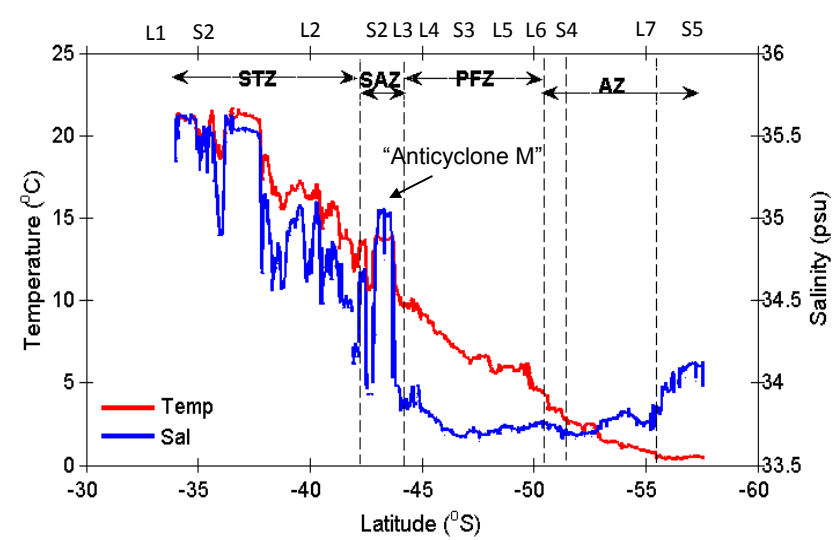

Fig. 2. Zonal description of the regions during the cruise (Sub Tropical Zone (STZ), Sub Antarctic Zone (SAZ), Polar Front Zone (PFZ) and Antarctic Zone (AZ). Surface temperature (red line) and surface salinity (blue line) with latitude along the cruise track measured by onboard continuous thermosalinograph. Sampling station identifiers are indicated above the plot. The position of Anticyclone $\mathrm{M}$ is indicated by an increase in temperature and salinity in the SAZ.

$\mathrm{NO}_{3}^{-}$concentrations $<0.05 \mu \mathrm{mol} 1^{-1}$ (Fig. 3a), while surface $\mathrm{Si}(\mathrm{OH})_{4}$ concentrations were typically $<2 \mu \mathrm{mol} 1^{-1}$ (Fig. 3b). Surface $\mathrm{NH}_{4}^{+}$concentrations were depleted $\left(<0.1 \mu \mathrm{mol} \mathrm{l}^{-1}\right)$, while urea concentrations were variable, ranging from $0.22-1.51 \mu \mathrm{moll}^{-1}$ (Table 2). In the SAZ, a gradual increase in surface $\mathrm{NO}_{3}^{-}$concentrations was observed ranging from $5-15 \mu \mathrm{mol} \mathrm{l}^{-1}$, but reaching $20 \mu \mathrm{mol} \mathrm{l}^{-1}$ below $100 \mathrm{~m}$ depth (Fig. 3a, Table 2). $\mathrm{Si}(\mathrm{OH})_{4}$ concentrations were depleted $\left(<2 \mu \mathrm{moll}^{-1}\right)$ throughout the surface $250 \mathrm{~m}$ (Fig. 3b). $\mathrm{NH}_{4}^{+}$concentrations were $<0.25 \mu \mathrm{moll}^{-1}$, but reached concentrations of up to $0.4 \mu \mathrm{mol}^{-1}$ between 40 $70 \mathrm{~m}$ depth (Table 2), while urea concentrations ranged from 1-1.5 $\mu \mathrm{moll}^{-1}$ (Table 2). In the PFZ, surface $\mathrm{NO}_{3}^{-}$concentrations reached $>20 \mu \mathrm{moll}^{-1}$ (Fig. 3a), while $\mathrm{Si}(\mathrm{OH})_{4}$ concentrations remained $<2 \mu \mathrm{mol} 1^{-1}$ in the upper $100 \mathrm{~m}$ of the water column (Fig. 3b). From north to south, surface $\mathrm{NH}_{4}^{+}$concentrations (above $100 \mathrm{~m}$ ) gradually increased from $<0.25$ to $>1.0 \mu \mathrm{mol}^{-1}$ (Table 1). Urea concentrations were higher than in the STZ and ranged from $\sim 1 \mu \mathrm{moll}^{-1}$ to a maximum of $3.27 \mu \mathrm{moll}^{-1}$ (at $\sim 60 \mathrm{~m}$, station S3). Universally high nutrient concentrations were observed in the AZ. $\mathrm{NO}_{3}^{-}$concentrations exceeded $30 \mu \mathrm{mol} 1^{-1}$ in the surface $\sim 100 \mathrm{~m}$ and continued to increase to a maximum of $\sim 40 \mu \mathrm{moll}^{-1}$ with depth (Fig. 3a). $\mathrm{Si}(\mathrm{OH})_{4}$ concentrations showed a steep north-south gradient from $<2 \mu \mathrm{moll}^{-1}$ north of the PF to $>60 \mu \mathrm{moll}^{-1}$ at the southern margin of the region (Fig. 3b). $\mathrm{NH}_{4}^{+}$and urea concentrations in the $\mathrm{AZ}$ reached 0.8 and $2 \mu \mathrm{mol} 1^{-1}$ in the euphotic layer. 

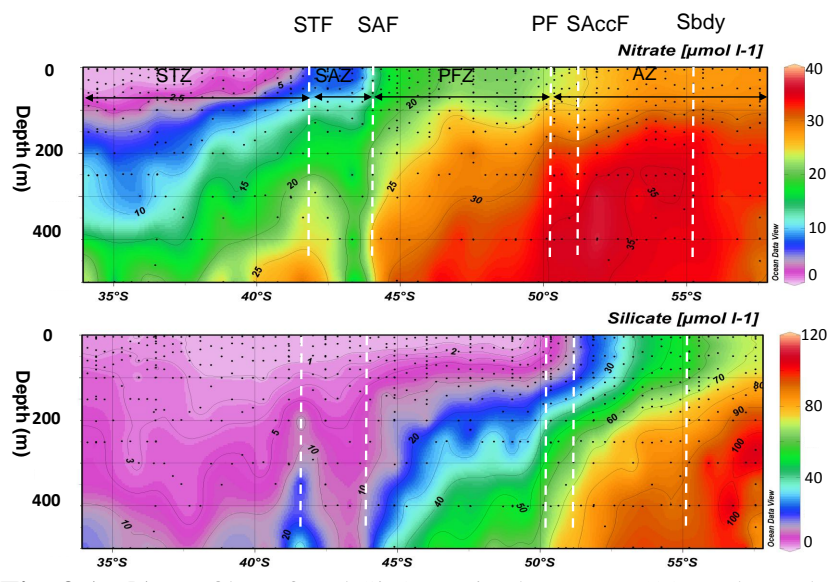

Fig. 3 (a, b) Profiles of and $\mathrm{Si}(\mathrm{OH})_{4}$ in the upper $500 \mathrm{~m}$ along the Bonus Goodhope Cruise track (taken from LeMoigne et al., 2011). It shows increasing surface nutrient concentrations with increasing latitude. Frontal positions are indicated by the white vertical dotted lines.

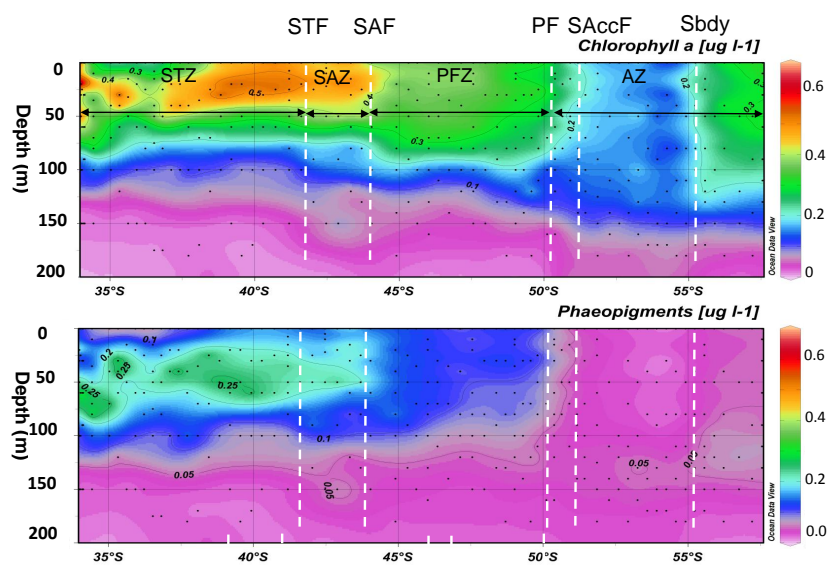

Fig. 3 (c, d) Profiles of chlorophyll-a and phaeopigments in the upper $200 \mathrm{~m}$ of the water column along the Bonus-Goodhope cruise track (Taken from Beker et al., 2011). Elevated pigment concentrations were observed in equatorward of the Subtropical Front. Frontal positions are indicated by the white vertical dotted lines.

\subsection{Chlorophyll- $a$}

In the STZ, euphotic zone chl- $a$ concentrations were highest, exceeding $0.4 \mu \mathrm{g} 1^{-1}$ with a sub-surface chl- $a$ maximum $\left(>0.5 \mu \mathrm{g}^{-1}\right.$ ) at $30-40 \mathrm{~m}$ (Fig. 3c See also Beker et al., 2011). A similar sub-surface maximum was observed for phaeopigments, although slightly deeper in the water column at $40-60 \mathrm{~m}$ (Fig. 3d). Size-fractionated chl- $a$ showed that picophytoplankton $(<2 \mu \mathrm{m})$ contributed $50.4 \%$ to total chl- $a$ (Fig. 4b). In the SAZ, chl- $a$ concentrations in the surface $\sim 40 \mathrm{~m}$ exceeded $0.4 \mu \mathrm{g} 1^{-1}$ (Fig. 3c), whereas a sub-surface maximum in phaeopigments $\left(>0.3 \mu \mathrm{g} 1^{-1}\right)$ was observed at $\sim 50 \mathrm{~m}$ (Fig. 3d). Size-fractionated chl- $a$ indicated that nano$(2-20 \mu \mathrm{m})$ and picophytoplankton contributed $60.2 \%$ and $39.8 \%$ respectively to total chl- $a$ concentrations, while no
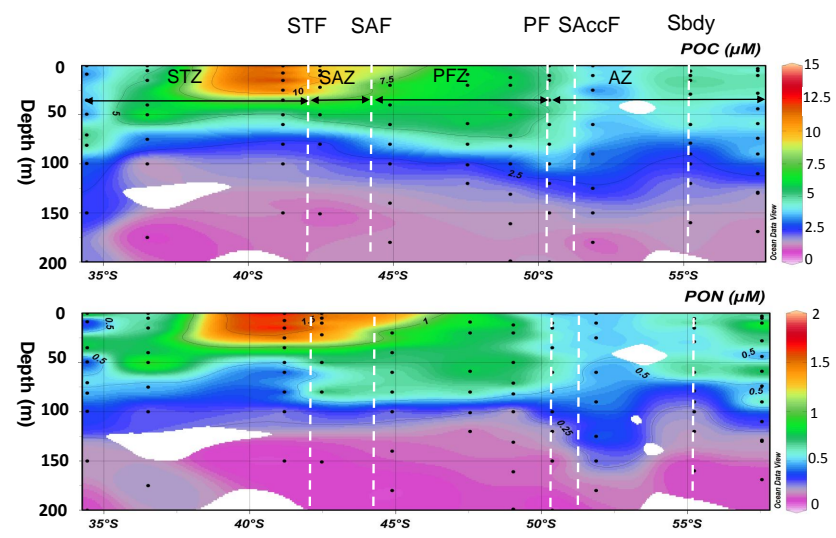

Fig. 3 (e, f) Profiles of Particulate Organic Carbon (POC) and Particulate Organic Nitrogen (PON) in the upper $200 \mathrm{~m}$ of the water column along the Bonus Goodhope cruise track. Highest concentrations were observed equatorward of the Sub-Antarctic Front. Frontal positions are indicated by the white vertical dotted lines.

microplankton (20-200 $\mu \mathrm{m})$ were measured (Fig. 4) in the SAZ. In the PFZ, chl- $a$ concentrations of $\sim 0.3 \mu \mathrm{g}{ }^{-1}$ were found in the upper $70 \mathrm{~m}$, (Fig. 3c). Phaeopigments typically exceeded $0.1 \mu \mathrm{g}^{-1}$ in the upper $50 \mathrm{~m}$ of the water column, and remained $<0.1 \mu \mathrm{gl}^{-1}$ below this depth (Fig. 3d). Size-fractionated chl- $a$ in surface samples was dominated by nanophytoplankton (54.3\%) throughout this region (Fig. 4), followed by picophytoplankton (30.6\%) and microphytoplankton (15\%). Chl- $a$ concentrations in the AZ between the $\mathrm{PF}$ and the SAccF, as well as south of the SBdy, ranged from 0.2 to $0.3 \mu \mathrm{g} \mathrm{l}^{-1}$, while a band of low chl- $a\left(<0.2 \mu \mathrm{g} \mathrm{l}^{-1}\right)$ was evident between the SAccF and the SBdy (Fig. 3c). Phaeopigments appeared completely absent in this region (Fig. 3d). In the AZ, nanoplankton comprised $61.9 \%$ of the phytoplankton community, while micro and picoplankton comprised 18.9 and $19.2 \%$ respectively (Fig. 4).

\subsection{POC and PON}

Maximum concentrations of POC $\left(14.1 \mu \mathrm{mol} 1^{-1}\right)$ and PON $\left(1.9 \mu \mathrm{mol}^{-1}\right)$ were found in the STZ just north of the STF (Fig. 3e, f) and confined to the upper $25 \mathrm{~m}$. Average PON concentrations over the euphotic layer of the STZ were $1.0 \pm 0.6 \mu \mathrm{mol}^{-1}$, with a mean euphotic zone $\mathrm{C}: \mathrm{N}$ ratio of $7.16 \pm 2.29$. In the SAZ, POC and PON concentrations in the surface $40 \mathrm{~m}$ reached a maximum of 7.7 and $1.5 \mu \mathrm{mol}^{-1}$ respectively (Fig. 3e, f, modified from Beker et al., 2011), with a mean euphotic zone $\mathrm{C}: \mathrm{N}$ ratio of $6.0 \pm 0.7$. In the PFZ, POC and PON averaged $5.3 \pm 0.5 \mu \mathrm{moll}^{-1}$ and $0.7 \pm 0.2 \mu \mathrm{mol}^{-1}$ respectively in the upper $60 \mathrm{~m}$ of the water column (Fig. 3e, f), with both decreasing below this depth. The average C:N ratio in the euphotic zone was $8.2 \pm 1.7$. In the AZ, POC and PON were typically $<4 \mu \mathrm{moll}^{-1}$ and $<0.5 \mu \mathrm{moll}^{-1}$ respectively (Fig. 3e, f) in the euphotic zone, with a mean C:N ratio of $7.4 \pm 2.7$. 
Table 2. List of data at each sampling station (including latitude positions) during the BGH cruise (MLD; m, sample depth; m, chl- $a$, $\mu$ g $1^{-1}$; POC and PON, $\mu \mathrm{moll}^{-1}$; nutrients, $\left.\mu \mathrm{moll}^{-1} ; \rho \mathrm{N}, \mathrm{nmol}^{-1} \mathrm{~d}^{-1}\right)$. The five sample depths at each station represent, with increasing depth, the $100 \%, 50 \%, 25 \%, 10 \%$ and $1 \%$ light depths. nd indicates no data.

\begin{tabular}{|c|c|c|c|c|c|c|c|c|c|c|c|c|}
\hline Station & MLD & Depth & Chl- $a$ & POC & PON & $\mathrm{NO}_{3}$ & $\mathrm{NH}_{4}$ & Urea & $\rho \mathrm{NO}_{3}$ & $\rho \mathrm{NH}_{4}$ & $\rho$ Urea & $f$ \\
\hline \multicolumn{13}{|l|}{ STZ } \\
\hline \multirow{5}{*}{$\begin{array}{l}\mathrm{L} 1 \\
\left(34.4^{\circ} \mathrm{S}\right)\end{array}$} & \multirow[t]{5}{*}{42} & 1.0 & 0.05 & 5.36 & 0.94 & $<0.05$ & 0.06 & 0.22 & 14.4 & 12.7 & 10.7 & 0.38 \\
\hline & & 5.0 & 0.05 & 8.13 & 0.68 & $<0.05$ & 0.05 & 0.33 & 9.5 & 26.0 & 30.5 & 0.14 \\
\hline & & 9.1 & 0.06 & 1.80 & 0.25 & $<0.05$ & 0.01 & 0.11 & 13.9 & 29.0 & 20.0 & 0.22 \\
\hline & & 35.0 & 0.11 & 4.78 & 0.82 & $<0.05$ & 0.02 & 0.33 & 21.2 & 34.5 & 49.8 & 0.20 \\
\hline & & 80.9 & 0.47 & 3.36 & 0.46 & 3.24 & 0.01 & 0.33 & 4.9 & 2.7 & 61.7 & 0.07 \\
\hline \multirow{5}{*}{$\begin{array}{l}\mathrm{S} 1 \\
\left(36.5^{\circ} \mathrm{S}\right)\end{array}$} & \multirow[t]{5}{*}{10} & 1.0 & 0.14 & 4.36 & 0.59 & $<0.05$ & 0.02 & 0.86 & 5.5 & 17.4 & 245.1 & 0.02 \\
\hline & & 7.3 & 0.16 & 4.50 & 0.62 & $<0.05$ & 0.01 & 0.76 & 20.1 & 18.4 & 280.2 & 0.06 \\
\hline & & 14.0 & 0.17 & 4.56 & 0.64 & $<0.05$ & 0.06 & 0.32 & 17.8 & 20.3 & 133.5 & 0.10 \\
\hline & & 40.2 & 0.20 & 5.42 & 0.71 & $<0.05$ & 0.10 & 0.86 & 18.2 & 16.3 & 347.5 & 0.05 \\
\hline & & 53.6 & 0.37 & 7.06 & 0.99 & $<0.05$ & 0.17 & 0.76 & 5.0 & 4.9 & 264.7 & 0.02 \\
\hline \multirow{5}{*}{$\begin{array}{l}\mathrm{L} 2 \\
\left(41.2^{\circ} \mathrm{S}\right)\end{array}$} & \multirow[t]{5}{*}{17} & 1.0 & 0.49 & 12.26 & 1.93 & 2.01 & 0.08 & 1.51 & 1.4 & 32.0 & 330.5 & 0.00 \\
\hline & & 3.3 & 0.54 & 12.26 & 1.93 & 2.01 & 0.08 & 0.65 & 37.5 & 37.7 & 169.0 & 0.15 \\
\hline & & 7.8 & 0.55 & 12.27 & 1.77 & 2.50 & 0.10 & 1.08 & 53.2 & 42.8 & 294.2 & 0.14 \\
\hline & & 15.3 & 0.56 & 14.12 & 1.88 & 3.86 & 0.03 & 0.76 & 56.6 & 17.6 & 105.0 & 0.32 \\
\hline & & 35.4 & 0.40 & 6.07 & 0.90 & 3.99 & 0.51 & 0.65 & 7.0 & 5.9 & 41.6 & 0.13 \\
\hline \multicolumn{13}{|l|}{ SAZ } \\
\hline \multirow{5}{*}{$\begin{array}{l}\mathrm{S} 2 \\
\left(42.5^{\circ} \mathrm{S}\right)\end{array}$} & \multirow[t]{5}{*}{75} & 1.0 & 0.35 & 7.70 & 1.30 & 11.04 & 0.09 & 1.26 & 41.0 & 15.9 & 50.0 & 0.38 \\
\hline & & 5.0 & 0.35 & 7.24 & 1.48 & 10.80 & 0.09 & 2.11 & 157.2 & 30.1 & 197.2 & 0.41 \\
\hline & & 9.6 & 0.35 & 7.68 & 1.15 & 10.80 & 0.09 & 0.84 & 96.7 & 21.8 & 57.6 & 0.55 \\
\hline & & 21.9 & 0.34 & 7.48 & 1.30 & 10.80 & 0.09 & 1.37 & 132.2 & 25.9 & 105.1 & 0.50 \\
\hline & & 50.6 & 0.38 & 5.78 & 0.89 & 6.03 & 0.09 & 1.26 & 54.7 & 1.8 & 46.7 & 0.53 \\
\hline PFZ & & & & & & & & & & & & \\
\hline & 47 & 1.0 & 0.25 & 4.78 & 0.78 & 17.79 & 0.31 & 0.71 & 30.7 & 23.4 & 26.4 & 0.38 \\
\hline$\left(44.9^{\circ} \mathrm{S}\right)$ & & 10.0 & 0.25 & 4.57 & 0.64 & nd & nd & 1.29 & nd & nd & 50.7 & nd \\
\hline & & 20.2 & 0.25 & 4.78 & 0.68 & nd & 0.31 & 0.82 & nd & 25.8 & 34.0 & nd \\
\hline & & 40.0 & 0.26 & 4.65 & 0.78 & nd & nd & 0.59 & nd & nd & 35.6 & nd \\
\hline & & 60.9 & 0.25 & 4.57 & 0.64 & 17.67 & 0.31 & nd & 56.8 & 5.1 & nd & 0.92 \\
\hline & 81 & 1.0 & 0.40 & 6.97 & 0.78 & 18.68 & 0.67 & 1.37 & 17.6 & 6.3 & 36.0 & 0.29 \\
\hline$\left(46.0^{\circ} \mathrm{S}\right)$ & & 10.6 & 0.40 & 6.67 & 0.80 & 18.68 & 0.67 & 0.91 & 33.1 & 22.0 & 18.2 & 0.45 \\
\hline & & 18.9 & 0.40 & 6.51 & 0.88 & 18.44 & 0.68 & 0.91 & 53.4 & 29.4 & 44.1 & 0.42 \\
\hline & & 20.3 & 0.40 & 5.63 & 0.75 & 18.44 & 0.68 & 1.03 & 45.6 & 35.7 & 15.3 & 0.47 \\
\hline & & 48.9 & 0.40 & 6.04 & 0.78 & 18.92 & 0.69 & 1.94 & 43.0 & 26.7 & 8.0 & 0.55 \\
\hline & 84 & 1.0 & 0.36 & 6.04 & 0.86 & 21.12 & 0.60 & 0.24 & 124.0 & 39.6 & 13.0 & 0.70 \\
\hline$\left(47.6^{\circ} \mathrm{S}\right)$ & & 5.0 & 0.36 & 6.04 & 0.86 & 21.12 & 0.60 & 0.85 & 72.0 & 24.6 & 16.9 & 0.63 \\
\hline & & 9.5 & 0.36 & 5.89 & 0.88 & 20.88 & 0.60 & 0.85 & 40.2 & 21.0 & 14.0 & 0.53 \\
\hline & & 19.7 & 0.36 & 5.58 & 0.74 & 21.12 & 0.60 & 1.58 & 28.3 & 48.1 & 106.8 & 0.15 \\
\hline & & 60.1 & 0.36 & 5.56 & 0.80 & 20.88 & 0.62 & 3.27 & 22.2 & 8.4 & 108.5 & 0.16 \\
\hline & 97 & 1.0 & 0.26 & 5.17 & 0.47 & 20.93 & 0.73 & 0.39 & 37.1 & 8.2 & 5.6 & 0.73 \\
\hline$\left(49.0^{\circ} \mathrm{S}\right)$ & & 3.9 & 0.26 & 5.17 & 0.47 & 20.93 & 0.73 & 0.39 & 20.6 & 9.3 & 3.0 & 0.63 \\
\hline & & 10.1 & 0.26 & 5.49 & 0.53 & 20.93 & 0.73 & 2.06 & 21.0 & 14.4 & 13.2 & 0.43 \\
\hline & & 13.9 & 0.28 & 5.19 & 0.47 & 20.93 & 0.73 & 1.42 & 39.1 & 18.8 & 15.3 & 0.53 \\
\hline & & 60.4 & 0.25 & 5.16 & 0.60 & 20.93 & 0.73 & 0.77 & 15.5 & 15.3 & 10.5 & 0.38 \\
\hline & 78 & 1.0 & 0.31 & 5.37 & 0.54 & 22.80 & 1.26 & nd & 14.6 & 4.3 & nd & 0.77 \\
\hline$\left(50.4^{\circ} \mathrm{S}\right)$ & & 5.7 & 0.31 & 5.37 & 0.54 & 22.80 & 1.26 & 1.58 & 18.1 & 6.2 & 20.1 & 0.41 \\
\hline & & 9.4 & 0.30 & 9.04 & 0.74 & 22.80 & 1.25 & 1.33 & 22.9 & 7.4 & 28.3 & 0.39 \\
\hline & & 15.2 & 0.30 & 5.23 & 0.47 & 22.80 & 1.26 & 1.94 & 23.5 & 11.5 & 48.4 & 0.28 \\
\hline & & 78.5 & 0.30 & 3.43 & 0.31 & 24.51 & 1.89 & 1.33 & 13.6 & 5.5 & 13.3 & 0.42 \\
\hline $\mathrm{AZ}$ & & & & & & & & & & & & \\
\hline S4 & 107 & 1.00 & 0.16 & 2.67 & 0.50 & nd & 0.80 & 2.00 & nd & 11.0 & 24.7 & nd \\
\hline$\left(51.8^{\circ} \mathrm{S}\right)$ & & 1.90 & 0.16 & 2.67 & 0.50 & 25.71 & 0.80 & 2.00 & 28.8 & 11.6 & 16.9 & 0.50 \\
\hline & & 13.50 & 0.17 & 2.72 & 0.50 & 25.71 & 0.79 & 2.19 & 20.9 & 8.5 & 12.5 & 0.50 \\
\hline & & 23.60 & 0.16 & 2.98 & 0.50 & 25.71 & 0.80 & 1.62 & 19.7 & 9.2 & 16.8 & 0.43 \\
\hline & & 88.30 & 0.16 & 2.60 & 0.40 & 25.96 & 0.79 & 1.43 & 10.8 & 7.1 & 8.7 & 0.41 \\
\hline & 69 & 1.0 & 0.25 & 5.37 & 0.54 & 28.08 & 0.46 & 0.83 & 28.0 & 14.4 & 11.0 & 0.52 \\
\hline$\left(55.6^{\circ} \mathrm{S}\right)$ & & 5.3 & 0.25 & 9.04 & 0.74 & 28.08 & 0.46 & 0.41 & 51.1 & 13.0 & 8.0 & 0.71 \\
\hline & & 13.5 & 0.24 & 5.23 & 0.47 & 28.08 & 0.43 & 1.33 & 42.3 & 15.0 & 19.4 & 0.55 \\
\hline & & 25.1 & 0.27 & 5.39 & 0.52 & 28.08 & 0.43 & 1.94 & 53.3 & 3.7 & 41.5 & 0.54 \\
\hline & & 109.9 & 0.28 & 2.05 & 0.19 & 29.76 & 0.31 & 1.33 & 45.4 & 14.3 & 18.4 & 0.58 \\
\hline & 90 & 1.0 & 0.33 & 4.48 & 0.76 & 27.81 & 0.61 & 1.68 & 47.5 & 20.0 & 29.3 & 0.49 \\
\hline$\left(57.6^{\circ} \mathrm{S}\right)$ & & 3.2 & 0.33 & 4.48 & 0.76 & 27.81 & 0.61 & 1.29 & 41.2 & 23.8 & 29.3 & 0.44 \\
\hline & & 8.5 & 0.33 & 4.63 & 1.03 & 27.81 & 0.61 & 2.06 & 45.2 & 27.6 & 43.4 & 0.39 \\
\hline & & 28.8 & 0.30 & 4.06 & 0.69 & 28.06 & 0.63 & 3.10 & 33.3 & 19.5 & 73.0 & 0.26 \\
\hline & & 90.0 & 0.21 & 3.55 & 0.68 & 28.06 & 0.62 & 1.16 & 36.1 & 22.8 & 21.1 & 0.45 \\
\hline
\end{tabular}




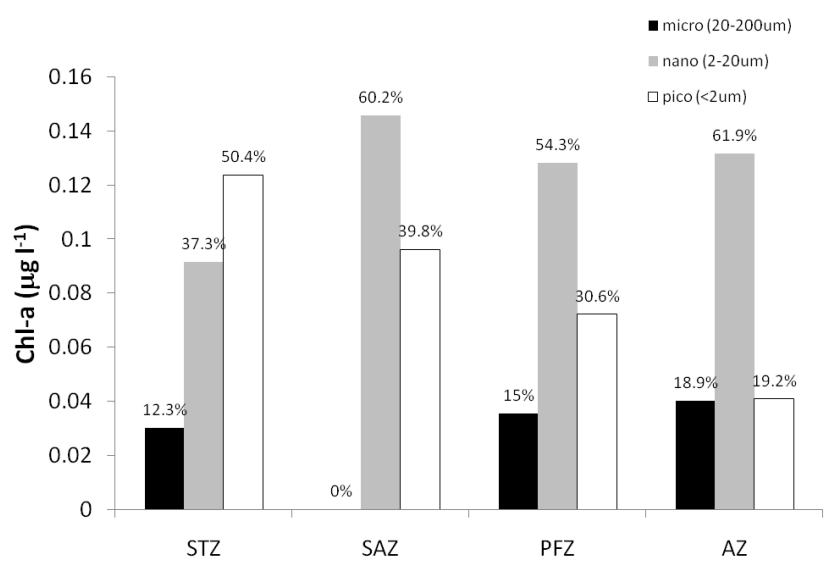

Fig. 4. Size fractionated chl- $a$ of surface samples in each region along the BGH cruise track. Bars indicate microphytoplankton (20$200 \mu \mathrm{m})$ given in black, nanophytoplankton $(2-20 \mu \mathrm{m}$ in grey and picophytoplankton $(<2 \mu \mathrm{m})$ in the white. Percentage of the total is presented at the top of each bar. It shows the decreasing contribution of picophytoplankton from north to south along the cruise track. Latitudes for the different zones are STZ (34-42.2 $\left.{ }^{\circ} \mathrm{S}\right)$, SAZ (42.2$\left.44.2^{\circ} \mathrm{S}\right), \mathrm{PFZ}\left(42.2-50.1^{\circ} \mathrm{S}\right)$ and the AZ $\left(50.1-57.5^{\circ} \mathrm{S}\right)$.

\subsection{Nitrogen uptake}

In the STZ $(n=3)$, $\rho$ urea dominated $\int \rho \mathrm{N}$ by $\sim 80 \%$ (Table 3 ), reaching a maximum rate of $347 \mathrm{nmoll}^{-1} \mathrm{~d}^{-1}$ at $40 \mathrm{~m}$ at station $\mathrm{S} 1$ (Table 2). purea was on average 8 times greater than $\rho \mathrm{NO}_{3}^{-}$or $\rho \mathrm{NH}_{4}^{-}$yielding a mean $f$-ratio of $0.24 \pm 0.22$ (Table 3 ). Specific uptake of urea $\left(V_{\text {urea }}\right)$ was on average 10 times greater than that of nitrate $\left(V_{\mathrm{NO}_{3}}\right)$ or ammonium $\left(V_{\mathrm{NH}_{4}}\right)$ (Fig. 5). In the $\mathrm{SAZ}(n=1) \rho \mathrm{NO}_{3}^{-}$ and $\rho$ urea reached maximum rates at $5 \mathrm{~m}$ of 157.3 and $197.2 \mathrm{nmol}^{-1} \mathrm{~d}^{-1}$ respectively (Table 2 ). These values decreased to 54.7 and $46.4 \mathrm{nmol}^{-1} \mathrm{~d}^{-1}$ respectively at the $1 \%$ euphotic depth. $\int \rho \mathrm{N}$ was $10.3 \mathrm{mmol} \mathrm{m}^{-2} \mathrm{~d}^{-1}$, with the highest contribution from $\int \rho \mathrm{NO}_{3}^{-}(49.4 \%)$ followed closely by $\int \rho$ urea $(43 \%)$ (Table 3$)$. The depth-integrated $f$-ratio for this station was 0.47 (Table 3). Specific uptake rates of nitrate $\left(V_{\mathrm{NO}_{3}}\right)$ and urea $\left(V_{\text {Urea }}\right)$ over the euphotic zone were $0.12 \pm$ $0.05 \mathrm{~d}^{-1}$ and $0.13 \pm 0.08 \mathrm{~d}^{-1}$ (Fig. 5), while $V_{\mathrm{NH}_{4}}$ was lower $\left(0.02 \pm 0.02 \mathrm{~d}^{-1}\right)$. In the PFZ $(n=5)$, euphotic zone $\rho \mathrm{NO}_{3}^{-}$, $\rho$ urea and $\rho \mathrm{NH}_{4}^{-}$remained below $50 \mathrm{nmoll}^{-1} \mathrm{~d}^{-1}$ (Table 2) and were typically lower than uptake rates in the STZ and SAZ. Station S3 exhibited the highest $\rho \mathrm{N}$ rates, compared to adjacent stations to the north or south. At station S3, $\rho \mathrm{NO}_{3}^{-}$decreased from $124.0 \mathrm{nmoll}^{-1} \mathrm{~d}^{-1}$ in the surface to $22.2 \mathrm{nmol}^{-1} \mathrm{~d}^{-1}$ at the base of the euphotic zone (Table 2). Conversely, $\rho$ urea increased from $13.0 \mathrm{nmol}^{-1} \mathrm{~d}^{-1}$ in the surface to $108.5 \mathrm{nmol}^{-1} \mathrm{~d}^{-1}$ at depth. Average $\int \rho \mathrm{N}$ for the PFZ was $5.26 \pm 2.2 \mathrm{mmol} \mathrm{m}^{-2} \mathrm{~d}^{-1}$ (Table 2), with the majority being due to $\int \rho \mathrm{NO}_{3}^{-}\left(1.97 \pm 0.46 \mathrm{mmol} \mathrm{m}^{-2} \mathrm{~d}^{-1}\right)$ and $\int \rho$ urea $\left(2.13 \pm 1.78 \mathrm{mmol} \mathrm{m}^{-2} \mathrm{~d}^{-1}\right)$, while $\int \rho \mathrm{NH}_{4}^{-}$averaged $1.16 \pm 0.41 \mathrm{mmol} \mathrm{m}^{-2} \mathrm{~d}^{-1}$, resulting in a mean $f$-ratio

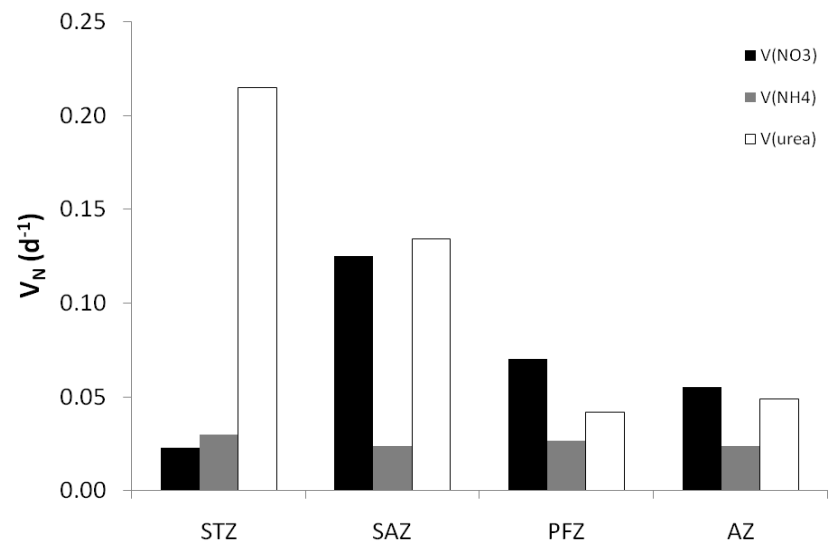

Fig. 5. Specific uptake $\left(V, \mathrm{~d}^{-1}\right)$ averaged over the euphotic zone for each region. It shows the contribution $V_{\mathrm{NO}_{3}}$ (black), $V_{\mathrm{NH}_{4}}$ (grey) and $V_{\text {Urea }}$ (white) as \% of total uptake, and a decreasing trend $V_{\text {Urea }}$ from north to south. Latitudes for the different zones are STZ $\left(34-42.2^{\circ} \mathrm{S}\right), \mathrm{SAZ}\left(42.2-44.2^{\circ} \mathrm{S}\right), \mathrm{PFZ}\left(42.2-50.1^{\circ} \mathrm{S}\right)$ and the AZ $\left(50.1-57.5^{\circ} \mathrm{S}\right)$.

of $0.41 \pm 0.11$ (Table 3). Average euphotic zone $V_{\mathrm{NO}_{3}}, V_{\mathrm{NH}_{4}}$ and $V_{\text {Urea }}$ were $0.07 \pm 0.07,0.03 \pm 0.1$ and $0.04 \pm 0.03 \mathrm{~d}^{-1}$ respectively (Fig. 6). In the $\mathrm{AZ}(n=3), \rho \mathrm{NO}_{3}^{-}, \rho \mathrm{NH}_{4}^{-}$ and $\rho$ urea also remained below $50 \mathrm{nmoll}^{-1} \mathrm{~d}^{-1}$ (Table 1). Mean $\int=\rho \mathrm{N}$ for the AZ was $6.46 \pm 4.21 \mathrm{mmol} \mathrm{m}^{-2} \mathrm{~d}^{-1}$ (Table 1), with up to $50 \%$ being derived from $\int \rho \mathrm{NO}_{3}^{-}$ $\left(3.43 \pm 2.68 \mathrm{mmol} \mathrm{m}^{-2} \mathrm{~d}^{-1}\right)$ (Table 3$)$. Mean $f$-ratio in the AZ was $0.45 \pm 0.11$ (Table 3). Specific nitrogen uptake rates in the AZ were similar to those observed in the PFZ (Fig. 5).

\section{Discussion}

In this section we discuss nitrogen uptake dynamics across four different hydrographic regions in the Atlantic sector of the Southern Ocean. We highlight regional differences in uptake rates, $f$-ratios and community size structure and investigate how these change in relation to MLD, temperature, nutrients and surface dissolved iron concentrations. We compare our data with other ${ }^{15} \mathrm{~N}$ estimates of production in the Southern Ocean, as well as with ${ }^{234} \mathrm{Th}$ based estimates of carbon export measured during the BGH cruise.

\subsection{Regional comparisons of nitrogen uptake}

\subsubsection{The Subtropical Zone}

Relatively high $\int \rho \mathrm{N}$ in the STZ (8.18 \pm $6.8 \mathrm{mmol} \mathrm{N} \mathrm{m}{ }^{-2} \mathrm{~d}^{-1}$ ) was dominated by $\int \rho$ urea $(\sim 79 \%)$, with $V_{\text {urea }}$ being ten times higher than $V_{\mathrm{NO}_{3}}$ or $V_{\mathrm{NH}_{4}}$, (Fig. 5), indicating significant regenerated production, as reflected by low $f$-ratios $(0.24 \pm 0.22)$. It is however unlikely that all the urea uptake is through phytoplankton production, as urea is easily assimilated by heterotrophic bacteria (Kirchman, 


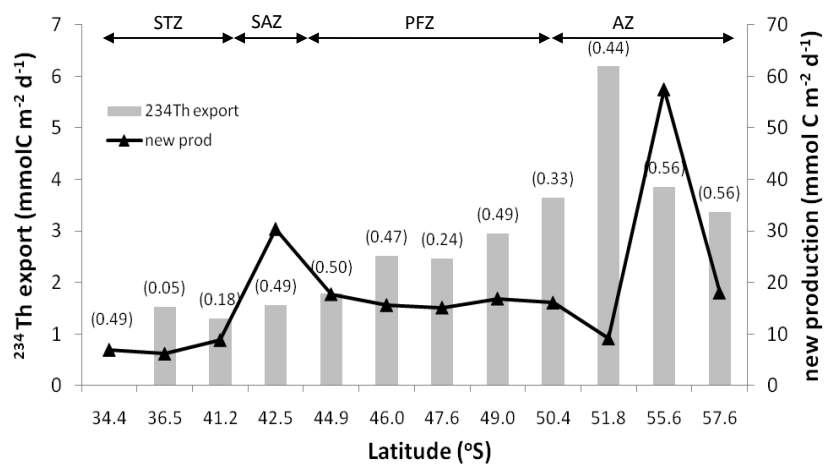

Fig. 6. Comparison between ${ }^{234} \mathrm{Th}$ carbon export (at $100 \mathrm{~m}$ ) (grey bars) and "new production" estimates (black triangles) in units mmol $\mathrm{C} \mathrm{m}^{-2} \mathrm{~d}^{-1}$ during BGH. $f$-ratio is indicated in brackets. New production calculated from $\int \rho \mathrm{NO}_{3}$ and the $\mathrm{C}: \mathrm{N}$ ratio. It shows the difference in magnitude of these proxies of carbon export. ${ }^{234} \mathrm{Th}$ data from Planchon et al. (2011). Latitudes for the different zones are STZ $\left(34-42.2^{\circ} \mathrm{S}\right), \mathrm{SAZ}\left(42.2-44.2^{\circ} \mathrm{S}\right), \mathrm{PFZ}\left(42.2-50.1^{\circ} \mathrm{S}\right)$ and the AZ $\left(50.1-57.5^{\circ} \mathrm{S}\right)$.

2000) which can contribute up to $25 \%$ of nitrogen uptake (Fouilland et al., 2007). Low new production rates in this region are likely due to limiting surface $\mathrm{NO}_{3}$ concentrations $\left(<0.05 \mu \mathrm{mol}^{-1}\right)$. Phytoplankton community structure was consistent with a typically regenerated-based community (Tremblay et al., 2000) with picophytoplankton dominating by $\sim 51 \%$ (Fig. 4). This is consistent with previous results of low $f$-ratios in the Indian $(f=0.07 \pm 0.03)$ (Thomalla et al., 2011) and Pacific basins (Sambrotto and Mace, 2000) (Table 2). These results imply that this region of the Southern Ocean is dominated by urea re-cycling within the microbial loop, with little carbon export, little atmospheric $\mathrm{CO}_{2}$ "draw-down", and conservation of nitrogen in surface waters (LeFevre et al., 1998; Smetacek et al., 2004).

\subsubsection{The Subantarctic Zone}

Station S2 in the SAZ exhibited only slightly higher total $\int \rho \mathrm{N}$ rates compared to those observed in the STZ, however this station showed a greater contribution of $\rho \mathrm{NO}_{3}^{-}(49.4 \%)$, which increased the $f$-ratio from 0.24 to 0.49 (Table 3 ). $V_{\mathrm{NO}_{3}}\left(0.12 \mathrm{~d}^{-1}\right)$ at this station was double that found in other regions (Fig. 5) along with the highest concentrations of chl$a\left(>0.5 \mu \mathrm{g} \mathrm{l}^{-1}\right)$, POC $\left(>7 \mu \mathrm{mol}^{-1}\right)$ and PON $\left(>1 \mu \mathrm{moll}^{-1}\right)$ (Fig. 3c, e, f). Specific uptake rates are known to provide information on the potential for macronutrient, light or iron limited growth, with higher values being characteristic of faster growth rates in nutrient and light replete environments. These high $V_{\mathrm{NO}_{3}}$ values thus suggest possible alleviation of iron stress (Lucas et al., 2007), along with sufficient light availability ( $M L D=45.2 \pm 17.1)$. It has been shown for oligotrophic regions that new production is enhanced within mesoscale eddy activity through the vertical injection of nutrients into the euphotic layer (Strass et al., 2002; Green- wood, 2007; Levy et al., 2009). This station was on the edge of a mesoscale hydrographic feature, "anticyclone M" (Arhan et al., 2011), observed just north of the SAF (Fig. 2). The proposed mechanism for the enhanced production and higher $f$-ratios at this station is enhanced vertical nutrient injection (including iron) at the edges of the anticyclone (Levy et al., 2009) along with an improved light environment associated with persistent shallow and stable mixed layers associated with the warm core eddy (Llido et al., 2005). Mesoscale eddies such as these provide important areas for local but significant $\mathrm{POC}$ export and biological $\mathrm{CO}_{2}$ draw-down in an overall HNLC Southern Ocean. $\int \rho \mathrm{N}$ rates in the SAZ of the Atlantic measured in this study $\left(10.3 \mathrm{mmol} \mathrm{m}^{-2} \mathrm{~d}^{-1}\right)$ were slightly higher than those measured in the Australian sector in late spring/early summer $\left(4.4 \pm 0.3 \mathrm{mmol} \mathrm{m}^{-2} \mathrm{~d}^{-1}\right)$ (Savoye et al., 2004) and were comparable to the Indian sector in late summer $\left(12.7 \pm 7.9 \mathrm{mmol} \mathrm{m}^{-2} \mathrm{~d}^{-1}\right)$ observations (Thomalla et al., 2011) (Table 3).

\subsubsection{The Polar Front Zone}

Total $\int \rho \mathrm{N}$ rates in the PFZ were the lowest of the four regions (Table 3), with low $f$-ratios of $0.41 \pm 0.11 . \int \rho$ urea and $V_{\text {urea }}$ were substantially lower than in the STZ and SAZ to the north (Fig. 5). High concentrations of ammonium and urea (Table 2) were observed in the PFZ indicating very active regeneration processes. Dilution of the isotopic ${ }^{15} \mathrm{NH}_{4}^{+}$and ${ }^{15} \mathrm{~N}$-urea uptake due to high regenerated nutrients released by bacteria and zooplankton grazers can potentially lead to an underestimation of the uptake rates of these substrates and consequently an overestimation of the $f$-ratio. Early work in the Scotia Sea showed that ammonium uptake can be underestimated by a factor of 2-3 in summer (Glibert et al., 1982). Although no $\mathrm{NH}_{4}^{+}$regeneration experiments were conducted during the cruise, one can expect that underestimation of regenerated uptake would further reduce the $f$-ratio's presented here. Although our cruise was in late austral summer, deep mixed layers in this region $(M L D=68.7 \pm 18.9 \mathrm{~m})$ relative to the $1 \%$ light depths $(61 \pm 11 \mathrm{~m})$ make light a potentially limiting factor to primary production and to $\mathrm{NO}_{3}^{-}$ uptake in particular considering its high light demand in comparison to $\mathrm{NH}_{4}^{+}$and urea uptake (Lucas et al., 2007; Cochlan, 2008). In addition, low surface Fe concentrations $<0.2 \mathrm{nmol}^{-1}$ (Chever et al., 2010) likely limit new production (Timmermans et al., 1998) promoting the dominance of small cells as size confers a competitive advantage for nutrients at low concentrations (Leynart et al., 2004). Smaller cells are however more susceptible to grazing by microzooplankton (Raven, 1986), which controls their biomass and at the same time contributes to potential regenerated production through $\mathrm{NH}_{4}^{+}$excretion (Glibert and Garside, 1992). Sizefractionated chlorophyll concentrations showed the PFZ to be dominated by nanophytoplankton (54\%, Fig. 4).

Several authors have found an increase in diatom concentration to be associated with the PF and attribute this 
Table 3. Comparison of depth integrated values of ${ }^{15} \mathrm{~N}$ uptake $\left(\mathrm{mmol} \mathrm{m}^{-2} \mathrm{~d}^{-1}\right)$ by phytoplankton in various regions of the Southern Ocean.

\begin{tabular}{|c|c|c|c|c|c|c|}
\hline Region/Description & $\int \rho \mathrm{NO}_{3}$ & $\int \rho \mathrm{NH}_{4}$ & $\int \rho$ Urea & $\Sigma \int \rho \mathbf{N}$ & $f$-ratio & \\
\hline Atlantic Sector (Summer 2008, BGH) & & & & & & this study \\
\hline $\mathrm{STZ}\left(34-41^{\circ} \mathrm{S}\right)$ & $1.01(0.3)$ & $0.69(0.3)$ & $6.47(6.7)$ & $8.18(6.8)$ & $0.24(0.22)$ & \\
\hline SAZ $\left(42-44^{\circ} \mathrm{S}\right)$ & 5.11 & 0.92 & 4.31 & 10.34 & 0.49 & \\
\hline PFZ $\left(45-50^{\circ} \mathrm{S}\right)$ & $1.97(0.5)$ & $1.16(0.4)$ & $2.13(1.8)$ & $5.26(2.2)$ & $0.41(0.11)$ & \\
\hline $\mathrm{AZ}\left(51-57^{\circ} \mathrm{S}\right)$ & $3.39(1.9)$ & $1.27(0.6)$ & $2.86(1.6)$ & $7.51(3.5)$ & $0.45(0.11)$ & \\
\hline Australian Sector (Spring 2001, CLIVAR-SR3) & & & & & & Savoye et al. (2004) \\
\hline SAZ/STF $\left(49-51.0^{\circ} \mathrm{S}\right)$ & & & & $4.4(0.3)$ & $0.53(0.26)$ & \\
\hline $\mathrm{PFZ}\left(54-57^{\circ} \mathrm{S}\right)$ & & & & $5.6(0.1)$ & $0.56(0.02)$ & \\
\hline $\mathrm{AZ}\left(61-65^{\circ} \mathrm{S}\right)$ & & & & $9.6(2.2)$ & $0.61(0.08)$ & \\
\hline Bellinghausen Sea & & & & & & Waldron et al. (1996) \\
\hline $\operatorname{SIZ}\left(56-64^{\circ} \mathrm{S}\right)$ & $1.8(1.2)$ & $10.9(3.9)$ & $9.9(0.4)$ & $18.0(11.9)$ & $0.1(0.01)$ & \\
\hline Indian Sector (CROZEX, Summer 2004) & & & & & & Lucas et al. (2007) \\
\hline Crozet-M3 bloom & $20.3(5.7)$ & $3.6(1.3)$ & $6.1(2.0)$ & $30.1(7.5)$ & $0.67(0.08)$ & \\
\hline Crozet-South of Plateau (HNLC) & $1.8(0.8)$ & $3.2(0.5)$ & $1.1(0.2)$ & $6.0(1.5)$ & $0.28(0.07)$ & \\
\hline Indian Sector (Summer 1994, ANTARES3) & & & & & & Mengesha et al. (1998) \\
\hline Kerguelen Plateau (PFZ, Stn A18; 49 S) & 5.7 & 3.5 & 2.8 & 11.9 & 0.48 & \\
\hline Kerguelen Plateau (PFZ, Stn A16; $\left.52^{\circ} \mathrm{S}\right)$ & 7.7 & 2 & 1 & 10.7 & 0.72 & \\
\hline Indian Sector (late Summer 1999, MIOS-4) & & & & & & Thomalla et al. (2011) \\
\hline $\mathrm{STZ}\left(31-40^{\circ} \mathrm{S}\right)$ & $3.76(4.2)$ & $19.83(15.0)$ & $22.30(17.8)$ & $46.07(33.5)$ & $0.07(0.03)$ & \\
\hline $\operatorname{SAZ}\left(41-46^{\circ} \mathrm{S}\right)$ & $0.94(0.2)$ & $5.26(2.3)$ & $6.48(5.4)$ & $12.67(7.9)$ & $0.09(0.04)$ & \\
\hline Pacific Sector (Summer 1997, US-JGOFS) & & & & & & Sambrotto and Mace (2000) \\
\hline PFZ $\left(57-61^{\circ} \mathrm{S}\right)$ & $2-5(2.3)$ & & & & $0.05-0.48$ & \\
\hline
\end{tabular}

to an increase in $\mathrm{Si}(\mathrm{OH})_{4}$ (Laubscher et al., 1993; Bathmann et al., 1997; Smetacek et al., 1997; Tremblay et al., 2002). Although it is possible for diatoms to fall within the nanophytoplankton size range, substantial increases in $\mathrm{Si}(\mathrm{OH})_{4}$ were only found south of the SACCF (Fig. 3b). Thus, although the percentage of microphytoplankton increased from $0 \%$ in the SAZ to $15 \%$ in the PFZ, the continued dominance by nanophytoplankton (54\%) was likely due to $\mathrm{Si}(\mathrm{OH})_{4}$ limitation of diatom growth and low surface Fe concentrations ( $<0.2 \mathrm{nmol}^{-1}$, Chever et al. 2010) favouring smaller cells. Similarly, low $\mathrm{Si}(\mathrm{OH})_{4}$ concentrations have been shown to play an important role in regulating nitrate uptake (Dugdale and Wilkerson, 1998; Sambrotto and Mace, 2000) such that the low $\mathrm{Si}(\mathrm{OH})_{4}$ concentrations in this region may have contributed to the low $\mathrm{NO}_{3}^{-}$uptake rates (1.97 $\left.\mathrm{mmol} \mathrm{m}^{-2} \mathrm{~d}^{-1}\right)$ and $f$-ratios found here. Our $\int \rho \mathrm{N}$ rates in the Atlantic PFZ $\left(5.26 \mathrm{mmol} \mathrm{m}^{-2} \mathrm{~d}^{-1}\right)$ were similar to those in the Australian sector $\left(5.6 \mathrm{mmol} \mathrm{m}^{-2} \mathrm{~d}^{-1}\right)$ and the HNLC Crozet sector $\left(6 \mathrm{mmol} \mathrm{m} \mathrm{m}^{-2} \mathrm{~d}^{-1}\right)$, but lower than the bloom region associated with naturally $\mathrm{Fe}$ fertilized Crozet (30.1 $\left.\mathrm{mmol} \mathrm{m}^{-2} \mathrm{~d}^{-1}\right)$ and Kerguelen $\left(11.9 \mathrm{mmol} \mathrm{m}^{-2} \mathrm{~d}^{-1}\right)$ Islands (Table 3). High concentrations of regenerated nutrients, low $f$-ratios and nanophytoplankton dominated communities implies an inefficient biological pump for this region which appears to be controlled by nutrient ( $\mathrm{Fe}$ and $\left.\mathrm{Si}(\mathrm{OH})_{4}\right)$ and light co-limitation and microzooplankton grazing.

\subsubsection{The Antarctic Zone}

A slight increase in $\int \rho \mathrm{N}$ was observed in the $\mathrm{AZ}$ $\left(7.5 \mathrm{mmol} \mathrm{m}^{-2} \mathrm{~d}^{-1}\right)$ relative to the PFZ $\left(5.3 \mathrm{mmol} \mathrm{m}^{-2} \mathrm{~d}^{-1}\right)$. The contribution of $\int \rho \mathrm{NO}_{3}^{-}$to total $\int \rho \mathrm{N}$ increased with a simultaneous increase in $f$-ratios to 0.45 indicating a slightly higher potential for carbon export. As with the SAZ, high ambient regenerated nutrient concentrations (Table 2) imply active regeneration processes occurring in the surface, however a decrease regenerated uptake rates, particularly urea uptake (Fig. 5) were observed relative to regions further north. An underestimation of the regenerated production in this region, could thus lead to an overestimate of the $f$-ratio. Although $\mathrm{Si}(\mathrm{OH})_{4}$ concentrations increase south of the SACCF (Fig. 3b), lowest chlorophyll concentrations are found in the region between the SACCF and the SBdy and it is only south of the Sbdy that chlorophyll concentrations increase (Fig. 3c). Although the mixed layer tends to deepen $(\mathrm{MLD}=93.9 \pm 14.7 \mathrm{~m}$ ) in the AZ, so too does the $0.1 \%$ light depth $(96 \pm 12 \mathrm{~m})$, making inadequate light the unlikely primary contributor to limited production. More likely, low surface Fe concentrations (Chever et al., 2010) characteristic of the late summer season are limiting phytoplankton growth despite sufficient irradiance (see also Boyd et al., 2001; Lucas et al., 2007). $\int \rho \mathrm{N}$ from this study $\left(7.5 \mathrm{mmol} \mathrm{m}^{-2} \mathrm{~d}^{-1}\right)$ was in a similar range to the $\int \rho \mathrm{N}\left(9.6 \mathrm{mmol} \mathrm{m}^{-2} \mathrm{~d}^{-1}\right)$ of the permanently open AZ in the Australian sector (Savoye et al., 2004). As expected however, these open ocean $\int \rho \mathrm{N}$ rates are up to $60 \%$ lower than those observed during bloom 
conditions in the Seasonal Ice Zone (SIZ) of the Bellinghausen Sea $\left(18.0 \pm 11.9 \mathrm{mmol} \mathrm{m}^{-2} \mathrm{~d}^{-1}\right)$ (Table 3). Lower open ocean $\int \rho \mathrm{N}$ rates compared to the SIZ can be ascribed to the lack of dissolved iron inputs from melting ice (Sedwick and DiTullio, 1997; Gao et al., 2003; Grotti et al., 2005) and a less favourable light environment through deep mixed layer depths $(93.9 \pm 14.7 \mathrm{~m})$ (Smith and Nelson, 1986). Although there is a slight increase in production and $f$-ratios in the AZ, relative to the PFZ, the ice free regions of this sector appear to have a relatively low potential for carbon export particularly in the late summer season due predominantly to Fe limitation.

\section{2 ${ }^{15} \mathrm{~N}$ estimates and ${ }^{234}$ Th export flux}

Carbon export derived from ${ }^{234} \mathrm{Th}$ deficits at $100 \mathrm{~m}$ revealed a north-south gradient, with the highest export fluxes (up to $6 \mathrm{mmol} \mathrm{C} \mathrm{m}^{-2} \mathrm{~d}^{-1}$ ) found south of the APF (Fig. 6, Planchon et al., 2011). Although the latitudinal trend in $f$-ratio estimates of carbon export were not as clear, with high export being associated with the eddy in the SAZ, there was a similar tendency for carbon export to increase with latitude (Fig. 6). New production estimates of carbon export were however 2-20 times greater in magnitude (Fig. 6) than ${ }^{234} \mathrm{Th}$ derived estimates. Reasons for this are numerous. Firstly, the two methods used to estimate carbon export are not intended to measure the same process. Although the rates are expected to be comparable in a steady state system or when averaged over large enough time and space scales, there is otherwise no a priori reason why the rates should be identical, bearing in mind $f$-ratio estimates of new production is potentially overestimated as the $f$-ratio is only estimated from $\rho \mathrm{NO}_{3}^{-}$. Stable isotope incubations measure $\mathrm{NO}_{3}^{-}$uptake at a discrete site over $12-24 \mathrm{~h}$ in the euphotic layer (typically $<60 \mathrm{~m}$ ) and may therefore not be representative of mesoscale averages. ${ }^{234} \mathrm{Th}$ deficit derived estimates of carbon export (at $100 \mathrm{~m}$ ) on the other hand encompass large spatial scales of $10 \mathrm{~s}$ to $100 \mathrm{~s}$ of kilometres (Buesseler et al., 1992) and a time period of $\sim 31$ days. Hence, in this instance ${ }^{234} \mathrm{Th}$ derived carbon fluxes more than likely represents a considerable averaging of episodically lower fluxes when compared to the short-term ${ }^{15} \mathrm{~N}$ incubations. Furthermore, ${ }^{234} \mathrm{Th}$ carbon flux estimates are derived by considering the $\mathrm{POC} /{ }^{234} \mathrm{Th}$ ratio of particles $>50 \mu \mathrm{m}$ and may well ignore a significant export flux within the $<50 \mu \mathrm{m}$ fraction. During BGH however, the $\mathrm{POC} /{ }^{234} \mathrm{Th}$ ratios of particles $>50 \mu \mathrm{m}$ and $<50 \mu \mathrm{m}$ were not very different. New production estimates, on the other hand do not discriminate on a size basis and represents the potential export of both dissolved and particulate material. This is consistent with other observations in both the Indian (Mengesha et al., 1998) and Pacific sector (Savoye et al., 2004) of the Southern Ocean and highlights the important role of this ocean in the global carbon cycle.

\section{Conclusions}

This paper presents ${ }^{15} \mathrm{~N}$-labelled nitrogen uptake measurements in the Atlantic Southern Ocean in late austral summer, 2008. $\rho \mathrm{N}$ in the oligotrophic STZ was dominated by $\rho$ urea, resulting in low $f$-ratios $(f=0.24)$. Size fractionated chl$a$ data is dominated by picophytoplankton $(>50 \%)$ and also indicative of a community based on regenerated phytoplankton production. It is unlikely that the measured $\mathrm{NH}_{4}^{-}$and urea uptake rates reflect only regenerated production in the $\mathrm{STZ}$, given that the uptake estimates based on ${ }^{15} \mathrm{~N}$ uptake does not account for heterotrophic bacterial activity. This probably results in an overestimation of urea uptake and underestimation of the $f$-ratio in the STZ. However, given the low concentrations of $\mathrm{NO}_{3}^{-}$in the surface waters of the STZ $\left(<0.05 \mu \mathrm{mol}{ }^{-1}\right)$ and the dominance of urea recycling within the microbial loop, with little carbon export. The greatest $\int \rho \mathrm{N}$ was observed in the SAZ and ascribed to enhanced nutrient supply and favourable light conditions associated with an anticyclonic eddy. Higher $f$-ratios were observed in the SAZ $(f=0.49)$, Polar Frontal Zone (PFZ, $f=0.41)$ and Antarctic zone (AZ, $f=0.45$ ) relative to the $\operatorname{STZ}(f=0.24)$ and indicate a higher contribution of $\rho \mathrm{NO}_{3}^{-}$relative to total $\rho \mathrm{N}$ and higher export potential in regions further south. New production estimates of carbon export (calculated from $\rho \mathrm{NO}_{3}^{-}$and the $\mathrm{C}: \mathrm{N}$ ratio) were lowest in the STZ (7.3 \pm $0.43 \mathrm{mmol} \mathrm{C} \mathrm{m}^{-2} \mathrm{~d}^{-1}$ ), compared to $30.4 \mathrm{mmol} \mathrm{C} \mathrm{m}^{-2} \mathrm{~d}^{-1}$ in the SAZ, $16.3 \pm 1.03 \mathrm{mmol} \mathrm{Cm}^{-2} \mathrm{~d}^{-1}$ in the PFZ and $28.2 \pm 25.8 \mathrm{mmol} \mathrm{C} \mathrm{m}^{-2} \mathrm{~d}^{-1}$ in the AZ. These carbon export estimates are comparable to observations carried out in the other sectors of the Southern Ocean (Waldron et al., 1995; Sambrotto and Mace, 2000; Savoye et al., 2004; Lucas et al., 2007). Increasing trends in ambient water column nutrient and surface iron concentrations corresponded with higher $\int \rho \mathrm{NO}_{3}^{-}$rates. Higher $f$-ratios south of the SAF reflects this, however, we suspect this to be an overestimation of the $f$-ratio given the elevated regenerated nutrient concentrations which indicate active regeneration processes assuming regeneration of nitrate in the euphotic layer. The relatively low total $\rho \mathrm{N}$ rates are ascribed to late summer season sampling when nutrients are depleted prior to the winter resupply. Comparison of our $f$-ratio based estimates of carbon export with those from ${ }^{234} \mathrm{Th}$ data collected during the cruise revealed a similar tendency for carbon export to increase with latitude but no clear correlation was observed. In addition, new production estimates were 2-20 times greater in magnitude and likely the result of the different integration time scales for the two different methods.

Acknowledgements. We thank the captain, officers and the crew of the R/V Marion Dufresne for their invaluable assistance in completing the BGH survey. We acknowledge Frank Dehairs and Anne-Julie Cavagna for providing the unpublished ${ }^{234} \mathrm{Th}$ data collected during the cruise. We also thank Annick Masson, Audrey Guenneugues for providing the macronutrient, chl- $a$ and POC data. This work was supported by the Institut National des 
Sciences de L'Univers of the Centre National de la Recherche Scientifique, the French Polar Institute (Institut Polaire Emile Victor), the French Research Institute for Exploitation of the Sea, the National Agency for Research Funding (ANR), and the University of Brest/IUEM. This work was also funded through the Southern Ocean Carbon - Climate Observatory (SOCCO) programme and the CSIR Parliamentary Grant. S. J. Thomalla was supported through a SOCCO post doctoral fellowship funded by ACCESS and NRF/SANAP.

Edited by: F. Dehairs

\section{References}

Arhan, M., Speich, S., Messager, C., Dencausse, G., Fine, R. A., and Boye, M.: Anticyclonic and cyclonic eddies of subtropical origin in the subantarctic zone south of Africa, J. Geophys. Res., in press, doi:10.1029/2011JC007140, 2011.

Arrigo, K. R.: 2005. Marine microorganisms and global nutrient cycles, Nature, 437, 349-355, doi:10.1038/nature04158, 2005.

Arrigo, K. R., Van Dijken, G. L., and Bushinsky, S.: Primary production in the Southern Ocean, 1997-2006, J. Geophys. Res., 113, C08004, doi:10.1029/2007JC004551, 2008.

Baar, H. J. W. de Boyd, P. W., Coale, K. H., Landry, M. R., Atsuhsi, T., Assmy, P., Bakker, D. C. E., Bozec, Y., Barber, R. T., Brzezinski, M. A., Buesseler, K. O., Boyé, M., Croot, P. L., Gervais, F., Gorbunov, M. Y., Harrison, P. J., Hiscock, W. T., Laan, P., Lancelot, C., Law, C., Levasseur, M., Marchetti, A., Millero, F. J., Nishioka, J., Nojiri, Y., Oijen, T. van, Riebesell, U., Rijkenberg, M. J. A., Saito, H., Takeda, S., Timmermans, K. R., Veldhuis, M. J. W., Waite, A., and Wong, C. S.: Synthesis of Iron Fertilization Experiments: From the Iron Age in the Age of Enlightenment, in: The Oceans in a High- $\mathrm{CO}_{2}$ World, edited by: Orr, J. C., Pantoja, S., and Pörtner, H.-O., special issue of J. Geophys. Res. Ocean., 110, 1-24, 2005.

Banse, K.: Low seasonality of low concentrations of surface chlorophyll in the Subantarctic water ring: underwater irradiance, iron and grazing, Prog. Oceanogr., 37, 241-291, 1996.

Bathmann, U. V., Scharek, R., Klaas, C., Dubischar, C. D., and Smetacek, V.: Spring development of phytoplankton biomass and composition in major water masses of the Atlantic sector of the Southern Ocean, Deep-Sea Res. Pt. II, 44, 51-67, 1997.

Behrenfeld, M. J.: Abandoning Sverdrups's critical depth hypothesis on phytoplankton blooms, Ecology, 91, 997-989, 2010.

Beker B., Boye, M., Ras, J., Gelay, A., and Claustre, H.: Distribution patterns of taxonomy and pigments during the austral summer in the southeastern Atlantic and the Southern Ocean south of South Africa, Biogeosciences Discuss., in prep, 2011.

Bianchi, M., Feliatra, F., Treguer, P., Vincendeau, M.-A., and Morvan, J.: Nitrification rates, ammonium nitrate distribution in upper layers of the water column and in sediments of the Indian sector of the Southern Ocean. Deep-Sea Res. Pt. II, 44, 1017$1032,1996$.

Blain, S., Treguer, P., Belviso, S., Bucciarelli, E., Denis, M., Desabre, S., Fiala, M., Jezequel, V. M., Lefevre, J., Mayzaud, P., Marty, J.-C., and Razouls, S.: A biogeochemical study of the island mass effect in context of the iron hypothesis: Kerguelen Island, Southern Ocean, Deep-Sea Res. Pt. I, 48, 163-187, 2011.
Boyd, P. W.: The role of iron in the biogeochemistry of the Southern Ocean and equatorial Pacific: a comparison of in situ iron enrichments, Deep-Sea Res. Pt. II, 49, 1803-1821, 2002.

Boyd, P. W., Crossley, A. C., DiTullio, G. R., Griffiths, F. B., Hutchins, D. A., Queguiner, B., Sedwick, P. N., and Trull, T. N.: 2001. Control of phytoplankton growth by iron supply and irradiance in the Subantarctic Ocean: Experimental results from the SAZ Project, J. Geophys. Res. 106, 31573-31583, 2001.

Boyd, P. W., Jickells, T., Law, C. S., Blain, S., Boyle, E. A., Buesseler, K. O., Coale, K. H., Cullen, J. J., de Baar, H. J. W., Follows, M., Harvey, M., Lancelot, C., Levasseur, M., Owens, N. P. J., Pollard, R., Rivkin, R. B., Sarmiento, J., Schoemann, V., Smetacek, V., Takeda, S., Tsuda, A., Tumer, S., and Watson, A. J.: Mesoscale iron enrichment experiments 19932005: Synthesis and future directions, Science, 315, 612-617, doi:10.1126/science.1131669, 2007.

Buesseler, K. O., Bacon, M. P., Cochran, J. K., and Livingston, H. D.: Carbon and nitrogen export during the JGOFS North Atlantic Bloom Experiment estimated from 234Th:238U disequilibria, Deep-Sea Res. Pt. I, 39, 1115-1137, 1992.

Buesseler, K.O ., Benitez-Nelson, C. R., Moran, S. B., Burd, A., Charette, M., Cochran, J. K., Coppola, L., Fisher, N. S., Fowler, S. W., Gardner, W. D., Guo, L. D., Gustafsson, O., Lamborg, C., Masque, P., Miquel, J. C., Passow, U., Santschi, P. H., Savoye, N., Stewart, G., and Trull, T.: An assessment of particulateorganic carbon to thorium-234 ratios in the ocean and their impact on the application of 234Th as a POC flux proxy, Mar. Chem., 100, 213-233, 2006.

Caldeira, K. and Duffy, P. B.: The role of the Southern Ocean in uptake and storage of anthropogenic carbon dioxide, Science, 297, 620-622, 2000.

Chever, F., Bucciarelli, E., Sarthou, G., Speich, S., Arhan, M., Penven, P., and Tagliabue, A.: Physical speciation of iron in the Atlantic sector of the Southern Ocean, along transect from subtropical domain to the Weddell Sea Gyre, J. Geophys. Res., 115, C10059, doi:10.1029/2009JC005880, 2010.

Chisholm, S. W. and Morel, F. M. M. M.: What controls phytoplankton production in nutrient-rich areas of the open sea?, Limnol. Oceanogr., 36, U1507-U1511, 1991.

Clark, D., Rees, A. P., and Joint, I. R.: Ammonium regeneration and nitrification rates in the oligotrophic Atlantic Ocean: implications for new production estimates, Limnol. Oceanogr., 53, 52-62, 2008.

Cochlan, W. P.: Nitrogen uptake in the Southern Ocean, in: Nitrogen in the Marine Environment, edited by: Capone, D. G. Bronk, D. A., Mulholland, M., and Carpenter, E., Elsevier Press, 561-588, 2008.

Coale, K. H. and Bruland, K. W.: ${ }^{234} \mathrm{Th}:{ }^{238} \mathrm{Ur}$ disequilibria within the California Current, Limnol. Oceanogr., 30, 22-33, 1985.

Comiso, J. C., McClain, C. R., Sullivan C. W., Ryan, J. P., and Leonard, C. L.: Coastal Zone Color Scanner pigment concentration in the Southern Ocean and relationship to geophysical surface features, J. Geophys. Res., 98, 2419-2451, 1993.

Cullen, J. J.: On models of growth and photosynthesis in phytoplankton. Deep-Sea Res., 3, 667-683, 1990.

de Boyer Monte'gut, C., Madec, G., Fischer, A. S., Lazar, A., and Iudicone, D.: Mixed layer depth over the globalocean: An examination of profile data and a profile-based climatology, J. Geophys. Res., 109, C12003, doi:10.1029/2004JC002378, 2004. 
Dugdale, R. C. and Goering, J. J.: Uptake of new and regenerated forms of nitrogen in primary production, Limnol. Oceanogr., 12, 196-206, 1967.

Dugdale, R. C. and Wilkerson, F. P.: The use of ${ }^{15} \mathrm{~N}$ to measure nitrogen uptake in eutrophic oceans; experimental considerations, Limnol. Oceanogr., 31, 673-689, 1986.

Dugdale, R. C. and Wilkerson, F. P.: Low specific nitrate uptake rate - a common feature of high-nutrient, low-chlorophyll marine ecosystems, Limnol. Oceanogr., 36, 1678-1688, 1991.

Eppley, R. W. and Peterson, B. J.: Particulate organic matter flux and planktonic new production in the deep ocean, Nature, 282, 677-680, 1979.

Fouilland, E., Gosselin, M., Rivkin, R. B., Vasseur, C., and Mostajir, B.: Nitrogen uptake by heterotrophic bacteria and phytoplankton in Arctic surface waters, J. Plankton. Res., 29, 369-376, 2007.

Froneman, P. W., Perissinotto, R., and McQuaid, C. D.: Seasonal variation in microzooplankton grazing in the region of the Subtropical Convergence, Mar. Biol., 126, 433-442, 1996.

Gao, Y., Fan, S., and Sarmiento, J. L.: Aeolian iron input to the ocean through precipitation scavenging: A modeling perspective and its implication for natural iron fertilization in the ocean, J. Geophys. Res., 108, 4221, doi:200310.1029/2002JD002420, 2003.

Glibert, P. M. and Garside, C.: Diel variability in nitrogenous nutrient uptake by phytoplankton in the Chesapeake Bay plume, J. Plankton. Res., 14, 271-288, 1992.

Glibert, P. M., Biggs, D. C., and McCarthy, J. J.: Utilization of ammonium and nitrate during austral summer in the Scotia Sea, Deep-Sea Res., 29, 837-850, 1982.

Goeyens, L., Semeneh, M., Baumann, E. M., Elskens, M., Shopova, D., and Dehairs, F.: Phytoplankton nutrient utilization and nutrient signature in the Southern Ocean, J. Mar. Sys., 17, 143-157, 1998.

Grasshoff, K., Ehrhardt, M., and Kremling, K.: Methods of seawater analysis, Verlag Chemi Weinheim, New York, 1983.

Greenwood, J. E., Feng, M., and Waite, A. M.: A one-dimensional simulation of biological production in two contrasting mesoscale eddies in the south eastern Indian Ocean, Deep-Sea Res. Pt. II, 54, 1029-1044, 2007.

Grotti, M., Francesco, S., Carmela, I., and Roberto, F.: Trace metals distributions in coastal sea ice of Terra Nova Bay, Ross Sea, Antarctica, Antarct, Science, 17, 290-300, 2005.

Kirchman, D. L.: Uptake and regeneration of inorganic nutrients by marine heterotrophic bacteria, in: Microbial Ecology of the Oceans, edited by: Kirchman, D. L., John Wiley and Sons, New York, 261-288, 2000.

Korb, R. E. and Whitehouse, M.: Contrasting primary production regimes around South Georgia: large bloom vs high nutrient low chlorophyll waters. Deep-Sea Res. Pt. I, 51, 721-738, 2004.

Laubscher, R. K., Perissinotto, R., and McQuaid, C. D.: Phytoplankton production and biomass at frontal zones in the Atlantic sector of the Southern Ocean, Polar Biol., 13, 471-481, 1993.

Le Fèvre, J., Legendre, L., and Rivkin, R. B.: Fluxes of biogenic carbon in the Southern Ocean: Roles of large microphagous zooplankton, J. Mar. Sys., 17, 325-345, 1998.

Le Moigne, F. A. C., Boye, M., Masson, A., Corvaisier, R., Grossteffan, E., Guéneugues, A., Pondaven, P., and Nelson, D.: Biogeochemical features of the subtropical southeastern Atlantic and the Southern Ocean south off South Africa during the austral summer of the International Polar Year, Biogeosciences Discuss., in prep, 2011.

Levy, M., Klein, P., and Jelloul, M. B.: New production stimulated by high-frequency winds in a turbulent mesoscale eddy field, Geophys. Res. Lett., 36, L16603, doi:10.1029/2009GL039490, 2009.

Leynaert, A., Bucciarelli, E., Claquin, P., Dugdale, R. C., MartinJézéquel, V., Pondaven, P., and Ragueneau, O.: Effect of iron deficiency on diatom cell size and silicic acid uptake kinetics, Limnol. Oceanogr., 49, 1134-1143, 2004.

Llido, J., Garcon, V., Lutjeharms, J. R. E., and Sudre, J.: Event-scale blooms drive enhanced primary productivity at the Subtropical Convergence. Geophys. Res. Lett., 32, L15611, doi:10.1029/2005GL022880, 2005.

Lucas, M. I., Seeyave, S., Sanders, S., Moore, M. C., Williamson, R., and Stinchcombe, M.: Nitrogen uptake response to a naturally Fe fertilised phytoplankton bloom during the 2004/2005 CROZEX study, Deep-Sea Res. Pt. II, 54, 2138-2173, 2007.

Martin, J.: Glacial-interglacial $\mathrm{CO}_{2}$ change: the iron hypothesis, Paleoceanography, 5, 1-3, 1990.

Mengesha, S., Dehairs, F., Fiala, M., Elskens, M., and Goeyens, L.: Seasonal variation of phytoplankton community structure and nitrogen uptake regime in the Indian Sector of the Southern Ocean, Polar Biol., 20, 259-272, 1998.

Metzl, N., Tilbrook, B., and Poisson, A.: The annual $f \mathrm{CO}_{2}$ cycle and the air-sea $\mathrm{CO}_{2}$ flux in the sub-Antarctic Ocean, Tellus B, 51, 849-861 1999.

Moore, J. K. and Abbott, M. R.: Surface chlorophyll concentrations in relation to the Antarctic Polar Front: seasonal and spatial patterns from satellite observations, J. Mar. Sys., 37, 69-86, 2002.

Moore, C. M., Hickman, A. E., Poulton, A. J., Seeyave, S., and Lucas, M. I.: Iron-light interactions during the CROZet natural iron bloom and EXport experiment (CROZEX): II - Taxonomic responses and elemental stoichiometry. Deep-Sea Res. Pt. II, 54, 2066-2084, 2007.

Orsi, A. H., Whitworth, T., and Nowlin, W. D.: On the meridional extent and fronts of the Antarctic Circumpolar Current, DeepSea Res., 42, 641-673, 1995.

Planchon, F., Cavagna, A. J., and Dehairs, F.: Dynamics of biogenic particles in the Southern Atlantic Ocean as revealed by ${ }^{234} \mathrm{Th}$ proxy along the Bonus-Good-Hope transect from Cape Basin to Northern Weddell gyre, Biogeosciences Dicuss., in prep, 2011.

Pollard, R. T., Lucas, M. I., and Read, J. F.: Physical controls on biogeochemical zonation in the Southern Ocean, Deep-Sea Res. Pt. II, 49, 3289-3305, 2002.

Price, N. M., Ahner, B. A., and Morel, F. M. M.: The equatorial Pacific Ocean: Grazer-controlled phytoplankton in an iron-limited ecosystem, Limnol. Oceanogr., 39, 520-534, 1994.

Raven, J. A.: Physicological consequences of extremely small size for autotrophic organisms in the sea, Can. Bull. Fish. Aquat. Sci., 214, 1-70, 1986.

Raven, J. A.: The iron and molybdenum use efficiencies of plant growth with different energy, carbon and nitrogen sources, New Phytol., 109, 279-288, 1988.

Savoye, N., Dehairs, F., Elskens, M., Cardinal, D., Kopczynska, E. E., Trull, T. W., Wright, S., Baeyens, W., and Griffiths, F. B.: Regional variation of spring N-uptake and new production in the Southern Ocean, Geophys. Res. Lett., 31, L03301, 
doi:10.1029/2003GL018946, 2004.

Sambrotto, R. N. and Mace, B. J.: Coupling of biological and physical regimes across the Antarctic Polar Front as reflected by nitrogen production and recycling, Deep-Sea Res. Pt. II, 47, 3339$3367,2000$.

Sedwick, P. N. and DiTullio, G. R.: Regulation of algal blooms in Antarctic shelfwater by the release of iron from melting sea ice, Geophys. Res. Lett., 24, 2515-2518, 1997.

Seeyave, S., Lucas, M., Moore, C. M., and Poulton, A. J.: Phytoplankton productivity and community structure in the vicinity of Crozet Plateau during austral summer 2004/2005, Deep-Sea Res. Pt. II, 54, 2020-2044, 2007.

Sigman, D. M. and Boyle, E. A.: Glacial/Interglacial variations in atmospheric carbon dioxide, Nature, 407, 859-869, 2000.

Slawyk, G., Collos, Y., and Auclair, J. C.: The use of the I3C and $\mathrm{I} 5 \mathrm{~N}$ isotopes for the simultaneousmeasurements of carbon and nitrogen turnover rates in marine phytoplankton, Limnol. Oceanogr., 22, 925-932, 1977.

Smetacek, V., de Baar, H. J. W., Bathmann, U. V., Lochte, K., and Van Der Loeff, M. M. R.: Ecology and Biogeochemistry of the Antarctic Circumpolar Current during austral spring: a summary of Southern Ocean JGOFS cruise ANT X/6 of R/V Polarstern, Deep-Sea Res. Pt. II, 44, 1-21, 1997.

Smetacek, V., Assmy, P., and Henjes, J.: The role of grazing in structuring Southern Ocean pelagic ecosystems and biogeochemical cycles, Antarctic Sci., 16, 541-558, 2004.

Smith Jr., W. O. and Nelson, D. M.: Importance of ice edge phytoplankton production in the Southern Ocean, BioScience, 36, 251-257, 1986.

Sokolov, S. and Rintoul, S. R.: On the relationship between fronts of the Antarctic Circumpolar Current and surface chlorophyll concentrations in the Southern Ocean, J. Geophys. Res., 112, C07030, doi:10.1029/2006JC004072, 2007.

Speich, S., Arhan, M., and Fine, R. A.: Water masses and ocean dynamics along the BONUS-GoodHope transect, Ocean Sci., in prep, 2011.

Strass, V. H., Garabato, A. C. N., Pollard, R. T., Fischer, H. I., Hense, I., Allen, J. T., Read, J. F., Leach, H., and Smetacek, V.: Mesoscale frontal dynamics: shaping the environment of primary production in the Antarctic Circumpolar Current, Deep-Sea Res. Pt. II, 49, 3735-3769, 2002.
Takahashi, T., Sutherland, S. C., Sweeny, C., Poisson, A., Metzl, N., Tilbrook, B., Bates, N., Wanninkof, R., Feely, R. A., Sabine, C., Olafsson, J., and Yukihiro, N.: Global sea-air $\mathrm{CO}_{2}$ flux based on climatological surface ocean $p \mathrm{CO}_{2}$, and seasonal biological temperature effects. Deep-Sea Res. Pt. II, 49, 1601-1622, 2002.

Thomalla, S. J., Waldron, H. N., Lucas, M. I., Read, J. F., Ansorge, I. J., and Pakhomov, E.: Phytoplankton distribution and nitrogen dynamics in the Southwest Indian Subtropical gyre and Southern Ocean waters, Ocean Sci., 7, 113-127, doi:10.5194/os-7-1132011, 2011.

Timmermans, K. R., van Leeuwe, M. A., de Jong, J. T. M., McKay, R. M. L., Nolting, R. R., Witte, H. J., van Ooyen, J., Swagerman, M. J. W., Klooster, H., and DeBaar, H. J. W.: Iron stress in the Pacific region of the Southern Ocean: Evidence from enrichment bioassays, Mar. Ecol. Prog. Ser., 166, 27-41, 1998.

Treguer, P. and Jacques, G.: Dynamics of nutrients and phytoplankton, and fluxes of carbon, nitrogen and silicon in the Antarctic Ocean, Polar Biol. 12, 149-162, 1992.

Treguer, P. and LeCorre, P.: Manuel d'analyse des sels nitritifs dans l'eau de mer (utilisation de l'Autoanalyser 2. Technicon), 2nd ed. Univ. Bretagne Occidentale, 110 p., 1975.

Tremblay, J. E., Legendre, L., Klein, B., and Therriault, J. C.: Sizedifferential uptake of nitrogen and carbon in a marginal sea (Gulf of St. Lawrence, Canada): significance of diel periodicity and urea uptake, Deep-Sea Res. Pt. II, 47, 489-518, 2000.

Tremblay, J. E., Lucas, M. I., Kattner, G., Pollard, R., Strass, V. H., Bathmann, U., and Bracher, A.: Significance of the Polar Front Zone for large-sized diatoms and new production during summer in the Atlantic sector of the Southern Ocean, Deep-Sea Res. Pt. II, 49, 3793-3811, 2002.

Waldron, H. N., Attwood, C. G., Probyn, T. A., and Lucas, M. L.: Nitrogen dynamics in the Bellinghausen Sea during the Austral spring of 1992, Deep-Sea Res. Pt. II, 42, 1253-1276, 1995.

Whitehouse, M. J., Korb, R. E., Atkinson, A., Thorpe, S. E., and Gordon, M.: Formation, transport and decay of an intense phytoplankton bloom within the High-Nutrient low Chlorophyll belt of the Southern Ocean, J. Mar. Sys., 70, 150-167, 2008.

Yool, A., Martin, A. P., Fernandez, C., and Clark, D. R.: The significance of nitrification for oceanic new production, Nature, 447, 999-1002, 2007. 